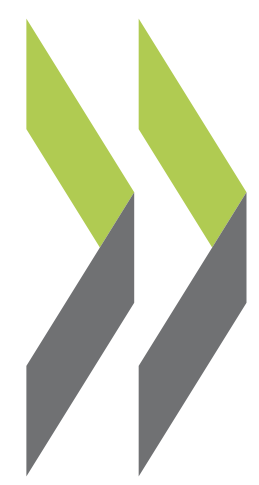

OECD Economics Department Working Papers No. 912

\author{
How to Improve \\ the Economic Policy
}

Framework for the Housing Philip Hemmings

Market in Israel 
Organisation de Coopération et de Développement Économiques

Organisation for Economic Co-operation and Development

06-Dec-2011

ECONOMICS DEPARTMENT

English - Or. English

HOW TO IMPROVE THE ECONOMIC POLICY FRAMEWORK FOR THE HOUSING MARKET IN ISRAEL

ECONOMICS DEPARTMENT WORKING PAPER No. 912

By Philip Hemmings

All OECD Economics Department Working Papers are available on the OECD Intranet website at www.oecd.org/eco/workingpapers

JT03312944

Document complet disponible sur OLIS dans son format d'origine

Complete document available on OLIS in its original format 


\section{ABSTRACT/RÉSUMÉ}

\section{How to improve the economic policy framework for the housing market in Israel}

Israeli house prices have risen by over $50 \%$ over the past three years. In part this reflects the fact that for several years housing construction had not kept pace with increases in the number of households. In response to these developments, hitherto sluggish planning-approval processes are being speeded up. However, in addition low interest rates have been boosting demand, and there are concerns that prices have already been driven to bubble levels. Efforts have been made to subdue demand, and the market has cooled off somewhat, but there remains a risk of a hard landing with a sharp downward price correction and a contraction in construction activity. Recent price developments are not the only economic issue in Israeli housing. As in a number of other OECD countries, housing policies favour home ownership through tax settings and subsidies for house purchase, potentially raising issues of labour mobility. More generally, housing support (public housing and rent support as well as subsidies for purchase) endeavours to fulfil an unusually wide policy agenda that goes beyond simply assisting low-income households with their housing needs. This Working Paper relates to the OECD 2011 Economic Survey of Israel (www.oecd.org/eco/surveys/Israel).

JEL classification codes: G21, I38, R21, R3, R31, R38, R52

Keywords: Israel, housing, housing market, Israeli housing market, Israeli house prices, rents, rental market, construction, planning regulation, mortgage, property tax, housing support, public housing, rent support, rent subsidy, mortgage support, mortgage subsidy.

$* * * * * * * * * * *$

\section{Marché du logement : comment améliorer le cadre de politique économique en Israël}

Ces trois dernières années, les prix des logements ont bondi de plus de $50 \%$ en Israël. Cette envolée tient notamment au fait que, pendant plusieurs années, la construction de logements n'a pas suivi le rythme de l'augmentation du nombre de ménages. Face à cette situation, des mesures ont été prises pour accélérer les procédures relatives à l'aménagement du territoire, jusqu'à présent très lentes. Cependant, le faible niveau des taux d'intérêt stimule la demande de logements, et certains craignent que la hausse des prix n'ait déjà pris des proportions de bulle. Les autorités israéliennes s'efforcent de tempérer la demande, et une certaine détente du marché a pu être observée, mais il subsiste un risque d'atterrissage en catastrophe, qui se traduirait par une correction brutale à la baisse des prix et une contraction de l'activité dans le secteur de la construction. Le marché du logement israélien n'est pas seulement affecté par la flambée récente des prix : comme dans d'autres pays de l'OCDE, les politiques du logement favorisent l'accession à la propriété au moyen de mesures fiscales et de subventions à l'achat, ce qui pourrait avoir des conséquences négatives sur la mobilité de la main-d'œuvre. D'une manière plus générale, l'aide au logement (qui englobe les logements sociaux, les allocations logement et les subventions à l'achat) est axée sur un éventail particulièrement vaste d'objectifs de l'action publique, qui va bien au-delà de l'aide aux ménages à bas revenus en matière de logement. Ce Document de travail se rapporte à l'Étude économique de l'OCDE d'Israël 2011 (www.oecd.org/eco/etudes/Israël).

Classification JEL G21, I38, R21, R31, R38, R52

Mots-clés: Israël, logement, marché de l'immobilier, marché de l'immobilier israélien, prix des logements israéliens, loyers, marché immobilier locatif, construction, règlementation relative à l'aménagement du territoire, prêts hypothécaires, impôt foncier, aide au logement, logement social, allocation logement, subvention à la location, prêts hypothécaires aidés, subventions des prêts hypothécaires.

Copyright () OECD, 2011 Application for permission to reproduce or translate all, or part of, this material should be made to: Head of Publications Service, OECD, 2 rue André Pascal, 75775 Paris Cedex 16, France. 


\section{Table of contents}

How to improve the economic policy framework for the housing market ..............................................

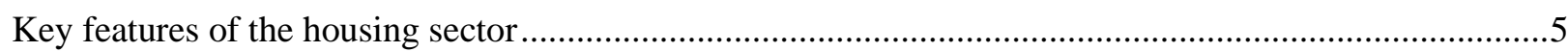

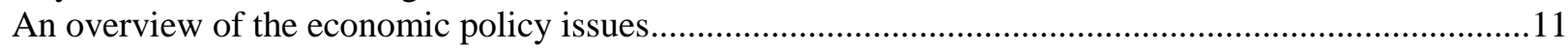

Supply responsiveness: scope for streamlining planning regulation ................................................12

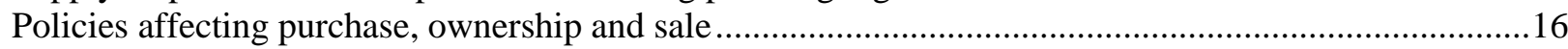

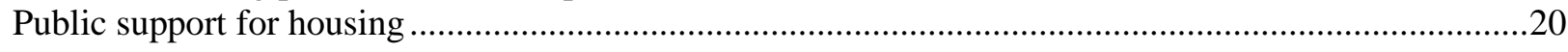

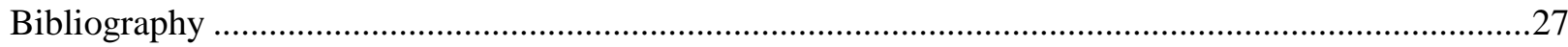

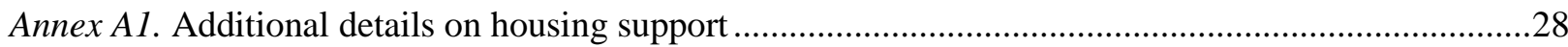

\section{Boxes}

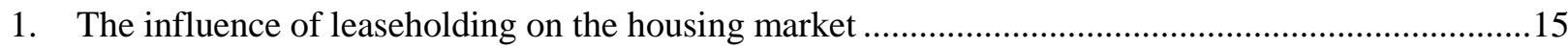

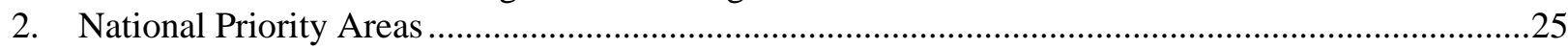

3. Recommendations for improving economic policy in the housing market .......................................26

\section{Tables}

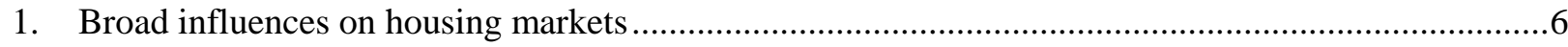

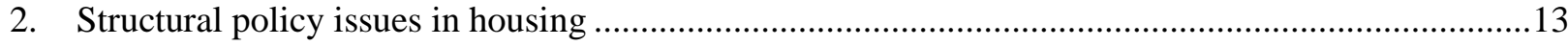

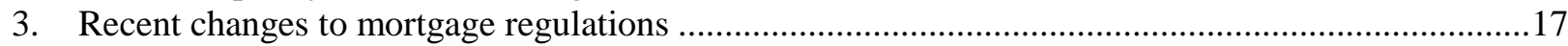

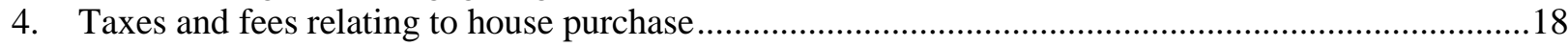

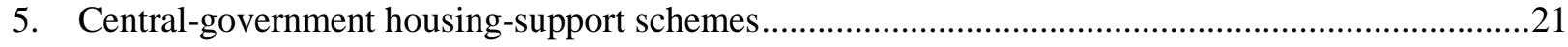

6. The points system used for eligibility to social housing the main mortgage support ........................24

\section{Figures}

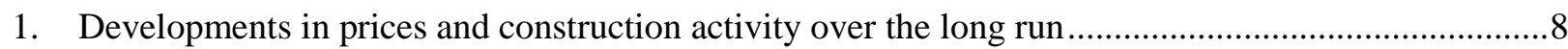

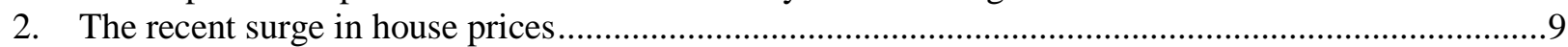

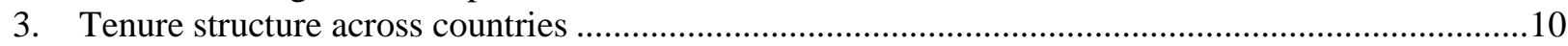

4. Regional distribution of households and regional house prices......................................................11

5. Price responsiveness of supply vis-a-vis scarcity of land and land-use regulations ..........................14

6. International comparison of transaction costs in house purchase .....................................................18

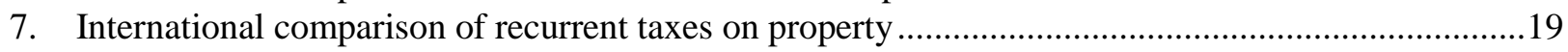

8. Central-government spending on rent subsidies and support for house purchase ..............................20

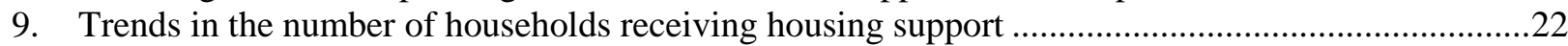

10. Tenant-landlord regulations in the private rental market, 2009................................................23

11. Examples of mortgages available under the general mortgage assistance scheme ...........................25

This document and any map included herein are without prejudice to the status of or sovereignty over any territory, to the delimitation of international frontiers and boundaries and to the name of any territory, city or area.

The statistical data for Israel are supplied by and under the responsibility of the relevant Israeli authorities. The use of such data by the OECD is without prejudice to the status of the Golan Heights, East Jerusalem and Israeli settlements in the West Bank under the terms of international law. 
ECO/WKP(2011)81 
ECO/WKP(2011)81

\title{
How to improve the economic policy framework for the housing market in Israel
}

\author{
By Philip Hemmings ${ }^{1}$
}

Rapid house-price increases since 2008 have prompted efforts to cool down the housing market to avoid the formation of a bubble. This paper traces the background to these developments and examines other policy issues in Israel's housing market. These include: regulations that guide the location and tenure of newly constructed dwellings; regulatory and tax influences on the process of buying, owning and selling dwellings; and targeted programmes assisting housing rental or purchase for some segments of the population. Policy recommendations are summarised at the end of the paper.

Some topics in Israeli housing are closely linked to geopolitical issues that are beyond the scope of OECD analysis. As noted in the previous Survey (Box 1.3), OECD Surveys are not intended to cover the territories known as the Golan Heights, the Gaza Strip or the West Bank including East Jerusalem. In terms of statistical coverage, however, for technical reasons this paper almost exclusively uses data that are regularly published and updated by the Central Bureau of Statistics (CBS) or other Israeli authorities, which include data relating to East Jerusalem, Israeli settlements in the West Bank and the Golan Heights. A sizeable number of Israelis live in these areas. According to figures calculated by the Israeli authorities for the OECD (OECD, 2011a), the total population of these areas, as of 2009, was 774 thousand, 444 thousand of which live in East Jerusalem, 289 thousand in other areas of the West Bank and 41 thousand in the Golan Heights. Israel's total population in 2009 was 7485 thousand, thus implying that those living in these areas represent $10.3 \%$ of the total. The share of the housing stock is likely to be of a similar magnitude.

\section{Key features of the housing sector}

Israel's housing market is driven by the same broad influences as in other countries (Table 1). Demographic and societal developments fundamentally govern demand for the number of dwellings and have been particularly influential in Israel's case. Population growth is high compared with most OECD economies and has at times been profoundly influenced by immigration. Furthermore, Israel's distinct religious and ethnic groups typically live in separate communities. In addition, variation in dwelling size, features and location mean that housing demand in a wider sense is driven by additional factors, such as the level of household income. Of course demand is divided between that for rental accommodation and owner-occupied housing; as in a number of other OECD countries, the latter is dominant. However, the housing market is also unusual in that most land is state-owned, and the market operates via long-term leases. The supply-side response to the various facets of housing demand depends fundamentally on space constraints (Israel has a high population density in its habitable areas) and on regulations governing

1. Head of the Israel Desk in the OECD Economics Department. This paper was produced for the OECD Economic Survey of Israel (http://www.oecd.org/eco/surveys/israel) published in December 2011 under the authority of the Economic and Development Review Committee. The author is indebted to OECD staff members Andrew Dean, Bob Ford and Peter Jarrett (Economics Department) and Willem Adema (Directorate for Employment, Labour and Social Affairs) for their valuable comments and to Françoise Correia for research assistance and to Mee-Lan Frank for editorial support. The paper has also benefitted enormously from discussions with policymakers and experts at the Ministry of Construction and Housing, the Ministry of Finance, and the Bank of Israel. 
housing construction and the replacement, renovation or extension of existing dwellings. The regulatory and planning system is strongly centralised in Israel, as is the administration of housing support (such as public housing and rent support).

Table 1. Broad influences on housing markets

\begin{tabular}{ll}
\hline \multirow{2}{*}{ Overall market } & \begin{tabular}{l} 
Influences \\
\cline { 2 - 3 } \\
hemand: demographics and other influences on the number and composition of \\
Supply: population density, planning and building regulation, competition in construction. \\
$\begin{array}{l}\text { Owner-occupier } \\
\text { sub-market }\end{array}$
\end{tabular}$\quad \begin{array}{l}\text { Tax treatment and fees relating to owner-occupancy (purchase, ownership and sale), } \\
\text { access to credit (mortgage regulation), housing support (mortgage support). }\end{array}$ \\
Rental sub-market & $\begin{array}{l}\text { Rental legislation and regulation, prices and conditions relative to home ownership, } \\
\text { housing support (public housing, rental support). }\end{array}$ \\
\hline
\end{tabular}

Source: Based on Andrews et al. (2011).

\section{Most land is state or quasi-state owned}

Most land in Israel (in total 93\%) is publicly or quasi-publicly owned and is managed by a special government agency (the Israel Land Administration, ILA). Some 81\% of Israel's land area is owned either directly by the state or is under the auspices of a special body (the Development Authority). The directly owned state land originates from the transfer of land from the British Mandate (which itself had inherited much of it from the Ottoman Empire), while land under the Development Authority originates from properties abandoned (mostly by Arab residents) during the 1948-49 war. In addition to the state-owned land and that under the Development Authority, $12 \%$ of land is owned by the Jewish National Fund (JNF), a non-profit organisation set up at the end of the $19^{\text {th }}$ century. In an agreement reached in 1960, the Fund placed its land holdings under ILA jurisdiction in exchange for half the seats on the ILA's governing board; this arrangement remains in place today. In line with the Fund's origins, leases of its land remain reserved for Jews. Nevertheless, the ILA can circumvent this. For instance, title swaps between JNF-owned and state-owned land are sometimes arranged, so that, for example, an Arab household can purchase a lease (Alterman, 2002a). There are, however, complications regarding title to some land in the Negev desert, where a longstanding dispute between the State of Israel and the local Bedouin community (OECD, 2010a). A government resolution was passed in 2011 that implements a solution along the lines proposed in 2008 by the government-established Goldberg Commission.

All in all, therefore, the ILA plays a key role in determining land use and hence strongly influences the pace of property development. The construction and sale of new dwellings is typically carried out by property developers. But, it is also fairly common for buyers to organise planning and construction directly through "purchase groups", an approach which, until recently, had tax advantages. A further consequence of the unusual system of land ownership is that most "homeowners" are in fact leaseholders, although changes are underway on this front (see below).

\section{A history of unusual price developments}

The recent surge in house prices reflects a longstanding pattern of atypical market development compared with other OECD countries. True, the long-run average rate of increase in real house prices (prices adjusted by consumer prices) has not been unusual (Figure 1, Panel A). For instance, from 1985 to 2010 the average real price growth was 3.5\%: higher than growth in United States but below that in a number of other countries. However, the pattern of prices has not followed trends elsewhere (Figure 1, 
Panel B). Real prices surged in the early 1990s when those in the United States and Europe were generally declining. Also, they remained flat during the long upswing elsewhere from the late 1990s. Nominal price developments have also been unusual. Until the late 1990s relatively high inflation meant that nominal price increases were much greater than in most OECD countries. Indeed, the cumulative increase in nominal prices since 1990 remains one of the highest in the OECD area. Deviations from a linear trend (calculated from Q1 1985, Figure 1, Panel C) have been substantial, ranging from 20\% below trend to nearly $16 \%$ above. Also, the correlation over time between real house-price growth and the pace of growth in the economy as a whole is not terribly strong (Figure 1, Panel D). This contrasts with residential property markets elsewhere, which typically track the business cycle quite closely (see for example: OECD, 2004; Catte et al., 2004; IMF, 2008).

The recent surge in house prices is partly linked to the lowering of interest rates in response to the 2008-09 global financial crisis. Prior to 2008 there had for some time been little movement in the representative house price (Figure 2, Panel A), but by the end of that year it was rising by about 10\% year on year. There was a brief period where price rises flattened and credit growth fell, but both subsequently picked up again. If a trend is passed through the month-on-month price changes, it suggests price appreciation peaked in mid-2009 at around 20\% annualised (year-on-year increases of course peaked somewhat later). More recently, credit growth has also slowed.

Rental-price movements have also been somewhat unusual. Various forms of dollar indexation emerged during the period of high inflation in the 1970s and 1980s and persisted in rental contracts (and some other sectors of the economy) long after inflation had been brought under control (see OECD, 2010b). Until 2007, close to $90 \%$ of rental contracts were denominated in US dollars, bringing a direct translation of exchange-rate movements into changes in the shekel value of rents. As a result, exchange-rate movements explained practically the entire variation in rental-price inflation (Figure 1, Panel E). This was of particular significance for monetary policy, as since 1999 the housing component of inflation has been based on rental costs. However, strong appreciation of the shekel against the dollar from mid-2007 until mid-2008 prompted a wholesale switch to shekel-denominated rents. Indeed, less than 10\% of contracts are now specified in dollars. As a result, the direct connection between exchange-rate movements and rental prices has practically disappeared.

\section{Demand and prices have been strongly affected by immigration}

Mass immigration following the collapse of the Soviet Union in the early 1990s prompted a surge in housing demand and construction activity. The main wave of immigration occurred in 1990 and 1991 (Figure 1, Panel F), and efforts to meet housing demand comprised mainly publicly initiated developments concentrated in peripheral areas in the form of mobile homes and rapidly constructed low-cost dwellings. ${ }^{2}$ This was followed by a second wave of construction activity, largely in central districts and initiated by the private sector, reflecting moves out of temporary dwellings and the gravitational economic pull from the central regions.

2. Government directly supplied housing and provided various incentives for private-sector construction. For instance, bonuses were awarded for construction within a certain time, and land leases were sold at discount prices. See Alterman (2002b) for further detail. 
Figure 1. Developments in prices and construction activity over the long run

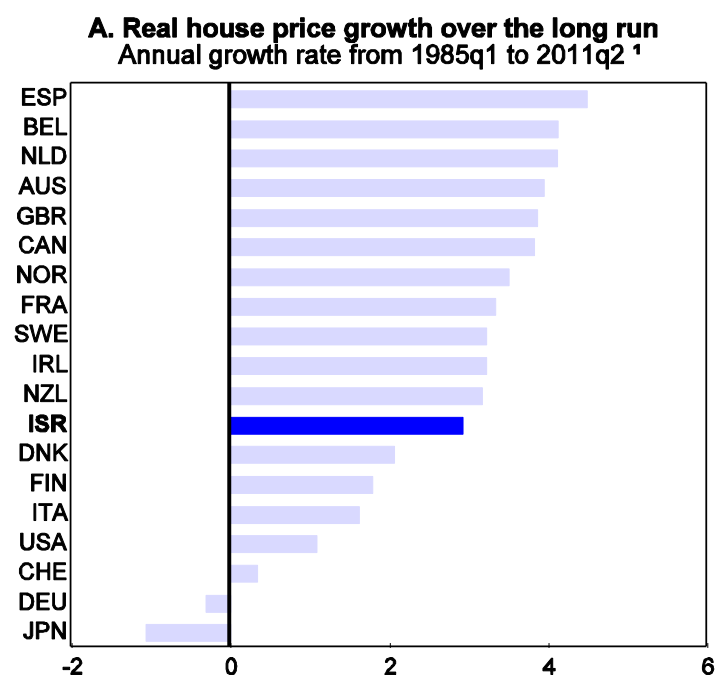

B. Real house price developments

Index $1985 q 1=100$

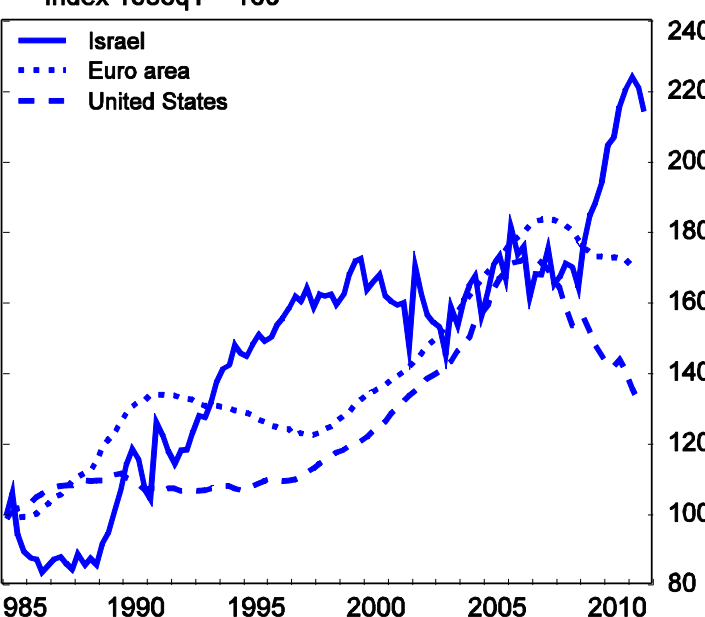

C. Deviation of real house price from trend

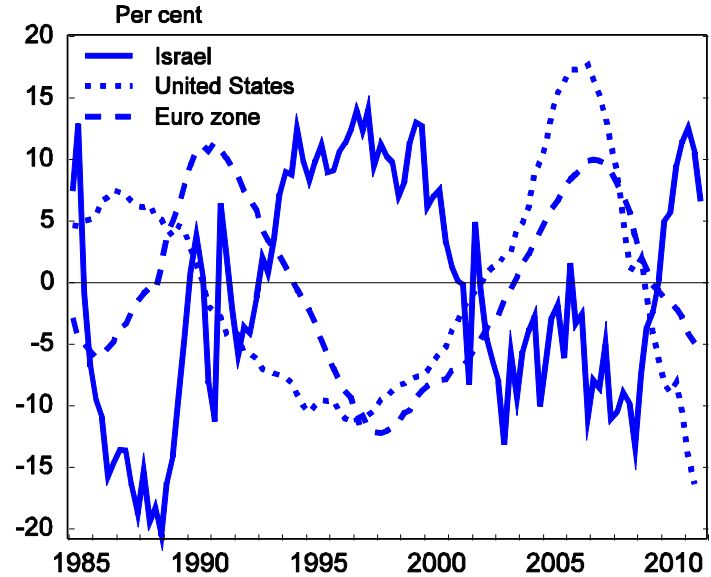

D. Growth in real house price

Year-on-year percentage change

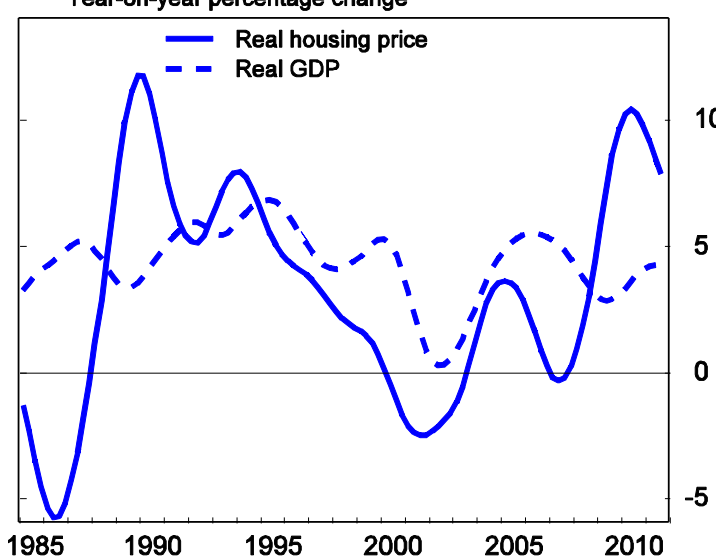

E. Developments in the rental market Year-on-year percentage change

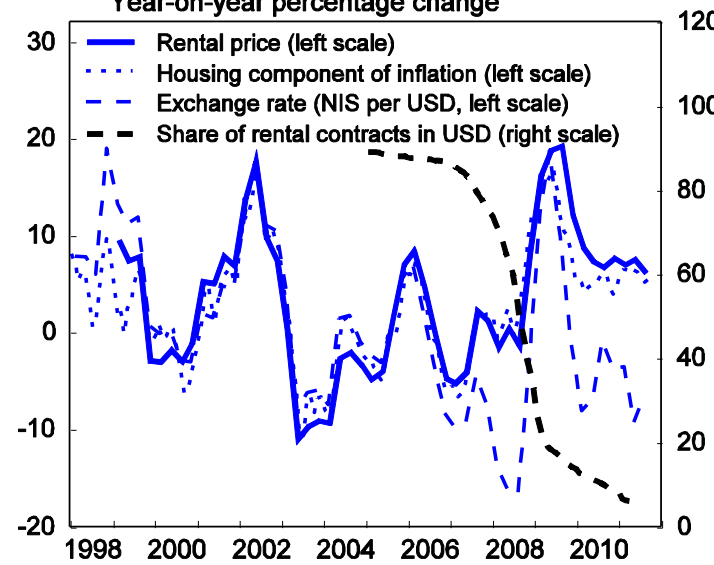

\section{F. Housing starts and population}

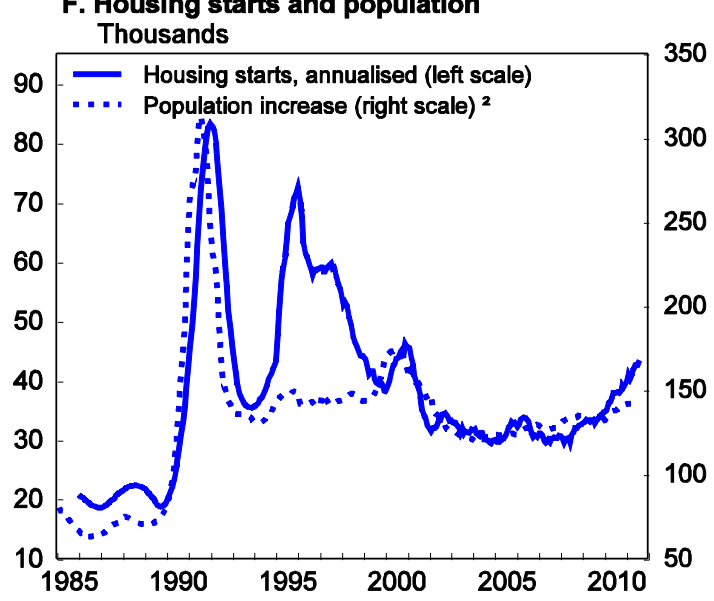

1. Or latest available data. House prices are deflated by the CPI for Israel, the private consumption deflator for the other countries.

2. Change from 12 months earlier ('000).

Source: Central Bureau of Statistics; Bank of Israel; OECD National accounts database; and OECD Economic Outlook 90 database. 
Figure 2. The recent surge in house prices
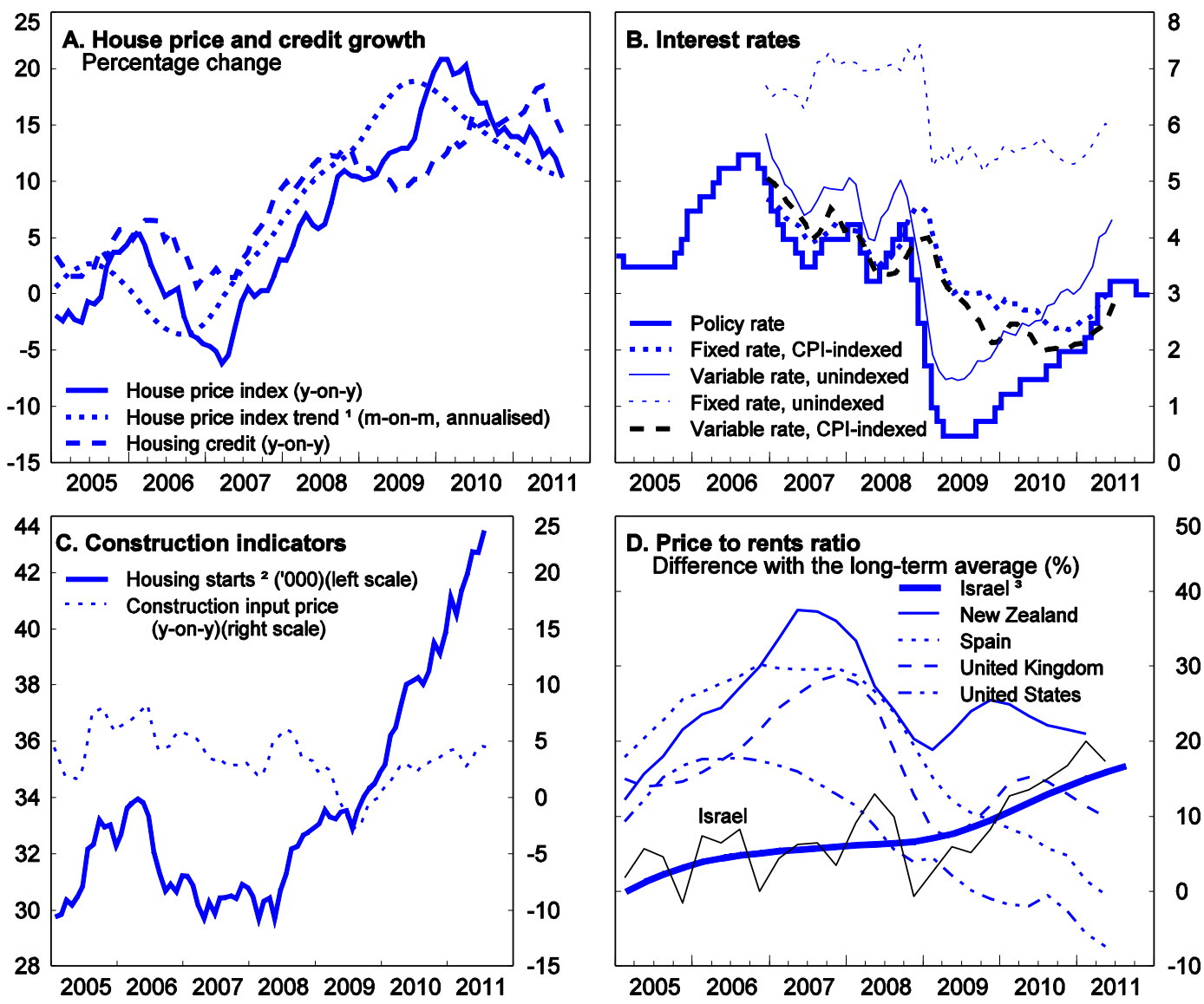

1. Trend has been calculated using a Hodrick Prescott filter, lambda $=400$.

2. Total over previous 12 months.

3. Data have been smoothed with a Hodrick Prescott filter, lambda $=100$

Source: Central Bureau of Statistics, Bank of Israel and OECD.

The wave of immigration also explains much of the price development during the 1990s. Prima facie, the surging prices in the early 1990s reflected straightforward supply shortages, despite the significant policy efforts to boost construction. But the situation was in fact more complex. Generous mortgage-subsidy schemes for the new immigrants (see below) are thought to have been a significant influence. Indeed, there is evidence confirming that sellers managed to directly capture some of the mortgage subsidy in the form of price increases. ${ }^{3}$ Furthermore, because the boost provided by the mortgage subsidies was only temporary, this partly explains why prices in the latter part of the 1990s and into the 2000s were rather flat. Some also argue (Bank of Israel, 2010, for instance) that the 1990s construction booms actually overshot demand, thereby also contributing to weak subsequent price growth.

3. Benchetrit and Czamanski (2009) present data on housing transactions in the Haifa region in a paper on immigration, home ownership and the role of mortgage subsidies in the 1990s. The data show that deflated prices of property bought using the subsidised mortgages rose more rapidly in the early 1990s than those purchased with regular mortgages. This implies that to some extent the mortgage subsidy was shared between immigrants, property developers and existing homeowners. The boost to prices in the mortgage-subsidy segment was short lived and was followed by a significant fall in prices in real terms while the remainder of the market remained relatively stable. 


\section{Most housing is owner occupied}

As later sections attest, settings in several policy areas deliberately promote home ownership and have without doubt had an impact. Around $70 \%$ of the dwelling stock is occupied by home owners, $22 \%$ by private rentals and only 6\% by public rentals (Figure 3 ). This tenure structure resembles that in English-speaking OECD countries such as Australia, the United Kingdom and the United States (see Andrews and Caldera-Sanchez, 2011). As in those countries, developments in prices and mortgage credit conditions are an important influence on many households' financial positions and can potentially have a profound impact on aggregate disposable income and consumption, as well as the stability of the financial system.

A very large share of Arab households (over 90\% according to Haider, 2008) are owner-occupiers, despite relatively low incomes on average. Indeed, Arab households own a large proportion of the 7\% of land area that is privately owned (see above). Properties are typically passed from one generation to the next, and so many families do not face mortgage (or rental) costs. In addition, the Arab population does not benefit from housing support for immigrants (see below), as permanent immigration is reserved for Jews only. Given this situation, it is inherently difficult to design housing support in Israel such that it plays a comprehensive and even-handed role in supporting low-income households (the Arab-Israeli community accounts for $20 \%$ of the total population and a larger share of low-income households, see Assessment and recommendations).

\section{Figure 3. Tenure structure across countries}

Per cent of dwelling stock, 2009

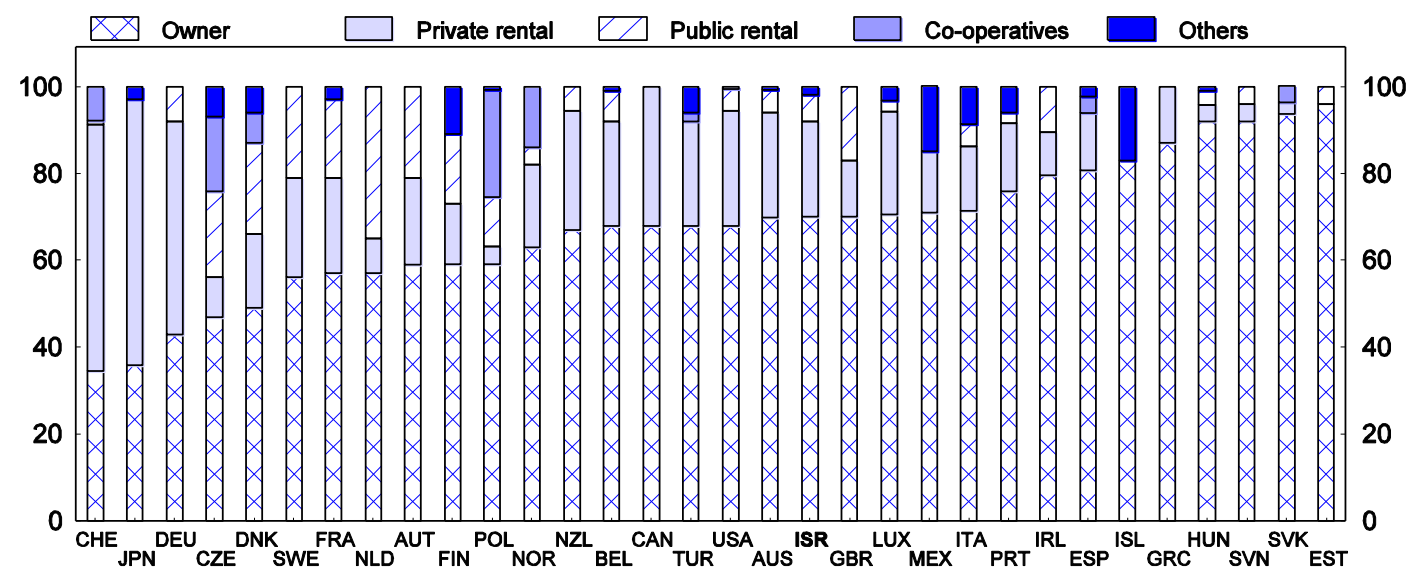

Source: Andrews et al. (2011), "Housing market policies and structural policies in OECD countries", OECD Economics Department Working Papers, No. 836.

\section{Geographic segmentation takes place along religious and ethnic lines}

Geographic segmentation of the population according to religion and ethnic background is pronounced. Most obvious in the available data are regional differences in the location of Arab and Jewish households. According to the Central Bureau of Statistics, the Arab population accounts for about half of households in the Northern District but relatively small shares of households in the Tel Aviv and Central Districts, which cover Israel's largest urban conurbation (Figure 4). Indeed, only 1.3\% of households in the Tel Aviv District are Arab-Israeli, compared with $16 \%$ for the country as a whole. Furthermore, the regional data do not reveal the full extent to which the different ethnic and religious communities live separately. Cities and towns tend to be divided into distinct Jewish and Arab neighbourhoods, and smaller 
localities are usually either predominantly Arab or Jewish. ${ }^{4}$ Also, within the Jewish population itself, communities are often dominated by particular groups. Ultra-orthodox households, in particular, often live in distinct parts of cities or in separate communities. Within the Arab-speaking population, some minorities also live in distinct areas, notably the Bedouin.

Figure 4. Regional distribution of households and regional house prices
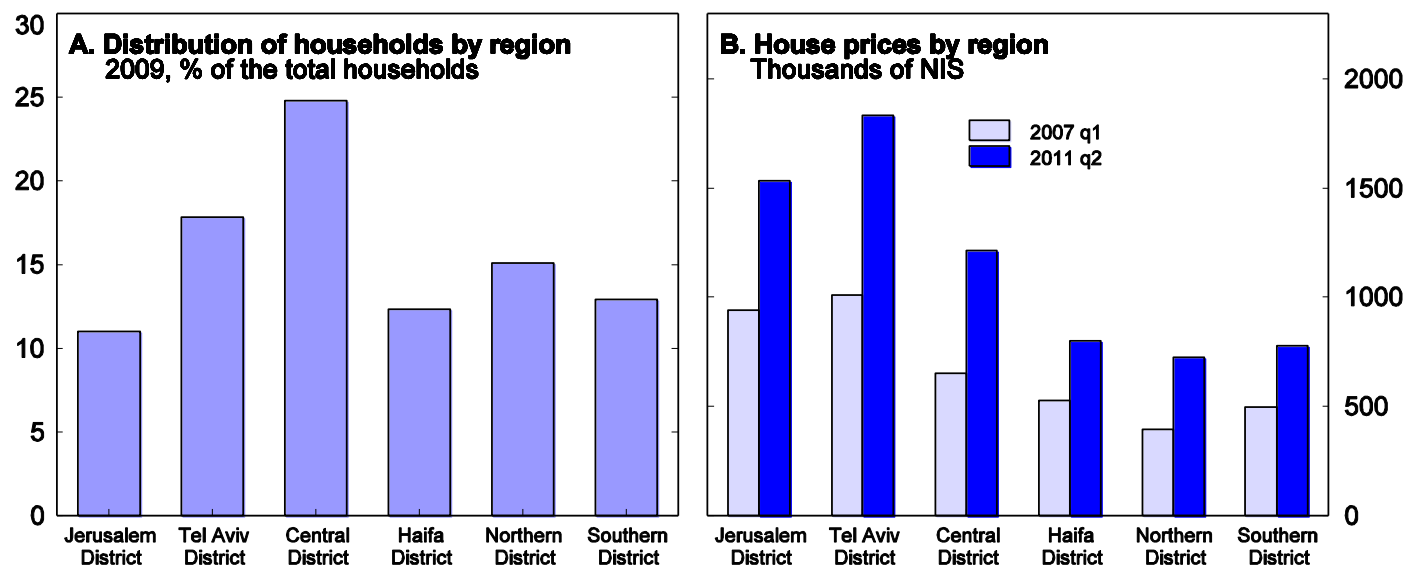

Source: Central Bureau of Statistics.

Regional and local segmentation of communities along cultural and other dimensions is common in other OECD countries but typically has less economic (and indeed political) significance than in Israel. In terms of economics, segmentation in theory reduces housing-market efficiency because the demand side will react less to price signals due to preferences on what type of community households are willing to live in. For some communities, segmentation may also be influencing access to labour markets. For example, Arab households may be reluctant to move to the economically prosperous area of Tel Aviv and surrounding districts because of the dearth of communities in which they might feel 'at home'. This said, Israel's relatively small geographic size means distances between many towns and cities are commutable, which widens the ability somewhat for households to exercise preferences as to where they live without prejudicing their employment opportunities.

Socio-economic segmentation is also illustrated by sizeable regional house-price differentials. House prices in the north and south of the country, where Arab communities are concentrated, are significantly lower than those in the central belt. For instance, the average price in the Northern District is currently about $30 \%$ of that in the Tel Aviv area, and the gap has widened in recent years (Figure 4). A priori, concerns about security in certain areas of the north and south are likely to be amplifying the price difference with the central belt. However, a study of regional price differences (Sayag, 2011) found that tax concessions on housing in border areas in some cases outweigh the negative effect on prices from security concerns.

\section{An overview of the economic policy issues}

A wide range of policy settings affect house prices and raise other issues. In broad terms they can be classified into: $i$ ) policies affecting housing construction; $i$ ) policies relating to the purchase, ownership and sale of dwellings; and iii) policies primarily motivated by social concerns. A synopsis of motivations,

4. Jewish and Arab communities can usually be identified by the colour of rooftop water tanks. In Jewish communities the tanks are generally either white or silver, while in Arab areas the tanks are typically black. 
typical issues and the Israeli situation is shown in Table 2. Most measures and programmes can be justified either in terms of market failure, or as vehicles for accommodating social or other policy agendas as conceptually embodied in the social welfare function. In terms of market impact, a number of policies primarily influence the split between the owner-occupied and rental segments and imply stronger or weaker overall demand for housing (not only in terms of the number of dwellings but also their size, quality and location) and housing credit. There are some common themes among the specific policy issues: risks of over-regulation, unwarranted support to middle- and upper-income earners and negative behavioural impacts of housing support.

The most immediate economic policy issue in housing is the rapid rise in prices in recent quarters. Admittedly, in recent months price increases according to the Central Bureau of Statistics' hedonically adjusted index have eased (Figure 2), and other data also suggest the market has come off the boil. However, this does not guarantee there will be a soft landing. The price-to-rent ratio is already some $20 \%$ above its long-term average value (Figure 2), and much more so for certain localities and types of apartment. By this measure the market may already be in dangerous territory, and recent market developments may mark the beginning of an undesirably fast contraction. The housing market in the United States collapsed when the price-to-rent ratio was only about $15 \%$ above its long-term average. This said, housing markets in Spain and the United Kingdom reached rent-price ratios of 30\% or more above average before sharp adjustment, and the ratio in New Zealand has reached even higher levels without sharp declines. It has been estimated that between one-third and one-half of house-price increases in Israel can be attributed to low interest rates (Bank of Israel, 2011). Although further normalisation of the central bank's policy rate has been put on hold (indeed, the rate was reduced in October 2011), it is believed that lagged effects from previous hikes will continue to temper price increases for a while. Macro-prudential and structural measures have also been taken to cool the housing market. Credit conditions on mortgage lending have been tightened in various ways, planning approval accelerated and tax settings altered to encourage the sale of properties (these are detailed below). If the recent slowing of the market indeed accelerates, then a reversal in some of these measures may be required to help avoid a 'hard landing' entailing a sharp correction in prices and property sales.

A second policy issue is that, as in many other OECD economies, policy settings and programmes have tended to favour home ownership excessively. This has potentially exacerbated the scale of recent price increases. Moreover, there is OECD-wide evidence that tilting policies towards home ownership can contribute to problems of labour immobility (Caldera-Sanchez and Andrews, 2011). Incentives for home ownership mainly include generous tax exemptions on capital gains and a general policy of encouraging home ownership for certain groups (especially in particular areas of the country). Indeed, housing support is unusual in several respects and only weakly and selectively targets low-income households. This represents a third structural weakness in housing policy.

\section{Supply responsiveness: scope for streamlining planning regulation}

Countries with comparatively scare land available for building new homes, such as Israel, tend to have housing supplies that are less responsive to higher prices. Thus, Israel's high population density puts the housing market at a natural disadvantage (Figure 5). In addition, at least according to one indicator, planning and building regulations are relatively cumbersome in international comparison. Such regulations can be viewed as mechanisms for overcoming externalities in land use (e.g. environmental externalities, impacts on transport systems and congestion). To some extent, therefore, there is probably a connection between the stringency of planning regulation and population density, because some externalities intensify when people live in close proximity. Nevertheless, it is unlikely that red tape in housing can be fully 
ECO/WKP(2011)81

Table 2. Structural policy issues in housing

\begin{tabular}{|c|c|c|c|}
\hline Policy & Theoretical justification & $\begin{array}{c}\text { Primary influences on } \\
\text { housing market }\end{array}$ & Issues (typical and Israel specific) \\
\hline \multicolumn{4}{|c|}{ Policies influencing construction activity (elasticity of supply) } \\
\hline $\begin{array}{l}\text { Land-use and building } \\
\text { regulation }\end{array}$ & $\begin{array}{l}\text { Externalities } \\
\text { (e.g. congestion) }\end{array}$ & Supply responsiveness & $\begin{array}{l}\text { Typical. Tendency for excessive regulation, due to } \\
\text { piecemeal accumulation of measures, and } \\
\text { resistance from vested interests to abandon or } \\
\text { reform regulation. } \\
\text { Israeli. Unusually high degree of centralisation in } \\
\text { planning. }\end{array}$ \\
\hline \multicolumn{4}{|c|}{ Policies relating to purchase, ownership and sale of housing } \\
\hline $\begin{array}{l}\text { Credit regulation } \\
\text { (especially for } \\
\text { mortgages) }\end{array}$ & $\begin{array}{l}\text { Micro-prudential } \\
\text { (financial stability) }\end{array}$ & $\begin{array}{l}\text { In broad terms, lighter } \\
\text { mortgage regulation } \\
\text { favours home } \\
\text { ownership, supports } \\
\text { demand and prices }\end{array}$ & $\begin{array}{l}\text { Typical. The financial crisis of } 2008-09 \text { has focused } \\
\text { attention on strengthening oversight and regulation } \\
\text { of housing credit. } \\
\text { Israel. Prima facie, few concerns about regulation } \\
\text { and oversight. Macro-prudential tools appear } \\
\text { adequate. }\end{array}$ \\
\hline $\begin{array}{l}\text { Taxes and fees at the } \\
\text { point of sale }\end{array}$ & $\begin{array}{l}\text { Coverage of } \\
\text { administrative costs, } \\
\text { fiscal revenue, brake on } \\
\text { price volatility }\end{array}$ & Favours renting & $\begin{array}{l}\text { Typical. Often considered as too high, given the } \\
\text { balance of pros and cons, particularly because } \\
\text { these are distortionary taxes. } \\
\text { Israel. Not a significant issue. }\end{array}$ \\
\hline $\begin{array}{l}\text { Income-tax treatment of } \\
\text { housing during } \\
\text { ownership (implicit rent } \\
\text { issue) }\end{array}$ & $\begin{array}{l}\text { Equal tax treatment } \\
\text { across assets }\end{array}$ & $\begin{array}{l}\text { In theory helps ensure } \\
\text { unbiased demand for } \\
\text { home ownership }\end{array}$ & $\begin{array}{l}\text { Typical. Information failures prevent "first-best" } \\
\text { solutions and for some countries treatment is } \\
\text { favourable; in effect, a tax sweetener for middle and } \\
\text { upper-income households. } \\
\text { Israel. Not a significant issue. }\end{array}$ \\
\hline Property tax & $\begin{array}{l}\text { Reliable tax base, } \\
\text { relatively non-distorting, } \\
\text { can (in theory) facilitate } \\
\text { local-government } \\
\text { democracy }\end{array}$ & $\begin{array}{l}\text { Depends how property } \\
\text { tax is levied }\end{array}$ & $\begin{array}{l}\text { Typical. Despite their theoretical attractions, } \\
\text { property taxes are typically not significant. One } \\
\text { explanation is that local governments are proficient } \\
\text { at tapping into central government funds instead } \\
\text { (which is preferable from their perspective). } \\
\text { Israel. Raises more revenue in property taxation } \\
\text { than many countries. }\end{array}$ \\
\hline $\begin{array}{l}\text { Exemptions from capital } \\
\text { gains on the sale of } \\
\text { property }\end{array}$ & $\begin{array}{l}\text { No obvious theoretical } \\
\text { justification }\end{array}$ & $\begin{array}{l}\text { Favours home } \\
\text { ownership, supports } \\
\text { demand and prices }\end{array}$ & $\begin{array}{l}\text { Typical. Exemption for owner-occupiers is very } \\
\text { widespread and effectively a sweetener for middle- } \\
\text { and upper-income households. } \\
\text { Israel. Extensive exemptions (though pared back } \\
\text { recently). }\end{array}$ \\
\hline \multicolumn{4}{|c|}{ Policies largely driven by social/ redistributive concerns or other agendas } \\
\hline Rental regulation & $\begin{array}{l}\text { Market imperfections, } \\
\text { notably unequal } \\
\text { bargaining power } \\
\text { between landlords and } \\
\text { tenants }\end{array}$ & $\begin{array}{l}\text { Strong protection of } \\
\text { tenants favours renting. } \\
\text { In some cases } \\
\text { regulation divides rental } \\
\text { market between } \\
\text { 'protected' and } \\
\text { 'unprotected' segments }\end{array}$ & $\begin{array}{l}\text { Typical. Risk of discouraging housing supply, } \\
\text { investment in dwelling maintenance and household } \\
\text { mobility. } \\
\text { Israel. Regulation may be too light. }\end{array}$ \\
\hline Public housing & $\begin{array}{l}\text { Social concerns (in } \\
\text { theory aligned with } \\
\text { social welfare function) }\end{array}$ & $\begin{array}{l}\text { Favours renting among } \\
\text { low-income households. } \\
\text { May influence } \\
\text { private-sector rental } \\
\text { prices. }\end{array}$ & $\begin{array}{l}\text { Typical. May crowd out private investment. Can } \\
\text { lead to (undesirable) residential segregation if poorly } \\
\text { designed/enforced. Reduced work incentives and } \\
\text { household geographic mobility. } \\
\text { Israel. Public housing sector is small; eligibility } \\
\text { conditions are unusual. }\end{array}$ \\
\hline $\begin{array}{l}\text { Rent allowances (in } \\
\text { private rental market) }\end{array}$ & $\begin{array}{l}\text { Social concerns (in } \\
\text { theory aligned with } \\
\text { social welfare function) }\end{array}$ & Favours renting & $\begin{array}{l}\text { Typical. Risk of "over consumption" of housing } \\
\text { among target populations (typically low-income } \\
\text { households). May reduce work incentives. } \\
\text { Israel. Similar issues may apply to some extent. }\end{array}$ \\
\hline Mortgage support & $\begin{array}{l}\text { Social concerns (in } \\
\text { theory aligned with } \\
\text { social welfare function) }\end{array}$ & $\begin{array}{l}\text { Favours home } \\
\text { ownership }\end{array}$ & $\begin{array}{l}\text { Typical. Does not typically assist very low-income } \\
\text { households. Sometimes prolonged and significant } \\
\text { fiscal expense. } \\
\text { Israel. Has been used extensively, with unusual } \\
\text { eligibility conditions and specific target populations } \\
\text { and regions. }\end{array}$ \\
\hline
\end{tabular}

Source: Based on Andrews et al. (2011). 
Figure 5. Price responsiveness of supply vis-a-vis scarcity of land and land-use regulations

Cross-country correlation

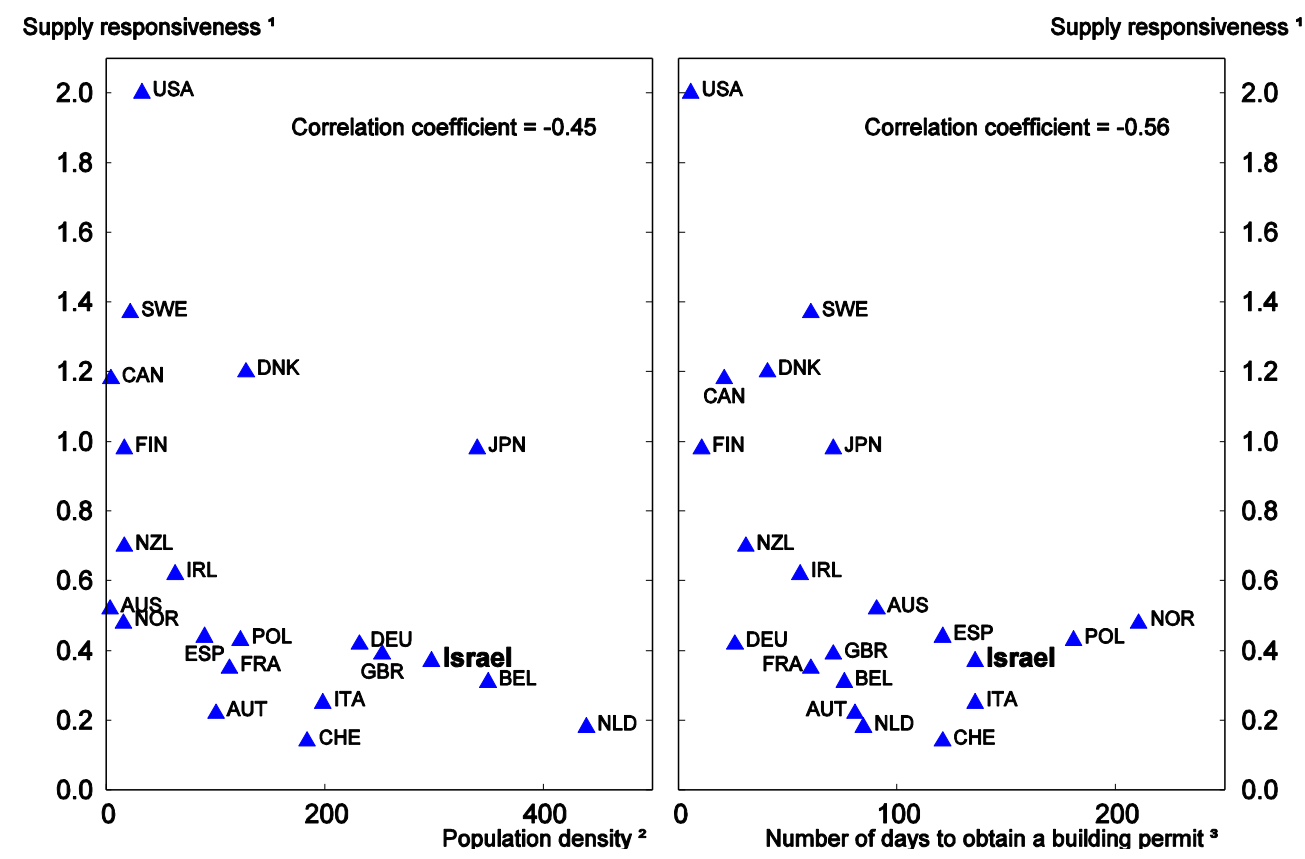

1. OECD estimates of country-specific supply responsiveness based on econometric methods.

2. Population density measured as population per $\mathrm{km} 2$.

3. The number of days to obtain a building permit is obtained from the World Bank Doing Business (2009) indicators.

Source: Johansson, Å. (2011), "Housing Policies in OECD Countries: Survey-based Data and Implications", OECD EConomics Department Working Papers, No. 836.

attributed to high population density, and there is without doubt room for streamlining regulation and procedures without excessively compromising the quality of outcomes. At least in the past, approval and permit processes have taken about $2 \frac{1}{2}$ years from the time land is released for development by the authorities to the moment when construction begins (Bank of Israel, 2011, p. 72).

Central government's role in property development should be pared back. Central government has considerable, and in many respects excessive, influence over the pace and location of property development in Israel. The associated planning and approval processes have been criticised by many as too rigid and slow, generating bottlenecks in the supply of new housing. Much of central government's influence stems from Israel's unique system of land ownership and, linked to this, the ILA's role in land management. Crucially, the ILA approves the release of land for development and therefore has a potentially profound influence on where and when new housing is built. In the past at least, development permits issued by the ILA appear to have given more priority to regional policies than market developments. For instance, according to Bank of Israel (2011, p. 75) new permits in 2009 and 2010 were concentrated in the Jerusalem region and the south, with rather less focus on the north, and notably the centre, where prices have been rising fastest.

Legislation allowing the conversion of land leases to full legal ownership in selected areas has been passed. In 2009 the Land Reform Bill included provisions allowing leaseholders on 200000 acres of land held by the ILA (about 5\% of ILA-regulated land) the option of purchase. Half the land will be made available by 2014, the remainder thereafter. A low regulated price will be set for land in peripheral areas, while the price in central districts will be based on estimated market value. The somewhat modest release 
of land for conversion partly reflects concerns that property developers could otherwise corner local land markets. Side conditions on purchase were added to the legislation as a further means to prevent this.

The option of switching to land ownership is broadly welcome and should be pursued further. This is the case even though legal ownership is unlikely to prompt an enormous improvement in housing-market efficiency. As Box 1 points out, in many respects the market already operates like those in other developed countries, despite the prevalence of leases on public and quasi-public land. Also, switching from leasing to ownership will not substantially alter planning regulations concerning land use. This said, legal ownership of land may improve access to credit in some instances. More importantly, conversion to legal ownership is a key building block in reducing the role of central government in the housing market and the often cumbersome red tape associated with it. Short of unforeseen difficulties with the current conversion option, additional releases of land allowing conversion to private ownership are recommended in the coming years.

\section{Box 1. The influence of leaseholding on the housing market}

Despite the fact that most property "owners" are in fact leaseholders, the housing market is very similar to one dominated by freehold ownership. A number of factors contribute to this, most notably:

- The importance of privately owned land is rather higher in the housing market than first appears, because it is concentrated in urban areas (much of the state-owned land is in largely uninhabitable areas, for instance in the Negev desert).

- When a lease on state (or quasi-state) property is first contracted, a lump sum is paid that represents the discounted value of rents for the term of the lease (typically 49 years). The calculation assumes annual rent is $5 \%$ of the estimated value of the property and uses a discount rate of $5 \%$. Over a 49 -year lease this means payment of $91 \%$ of the value of the property and is therefore very similar to purchase in this respect. Furthermore, in effect leases are for 98 years, because when the 'up-front' payment was first introduced, it was agreed that no payment for a second 49-year lease would be required. There is a general presumption that when these leases approach maturity, further costless extensions will be made, so leases would be effectively in perpetuity.

- Leases can be freely sold or transferred, thus creating a secondary market that closely resembles a 'normal' property market. The time-to-run on the lease has (at least to date) had no bearing on the price in this secondary market because of the 'perpetual' nature of the leases just described.

Nevertheless some features of the market remain unusual, in particular:

- $\quad$ Leasing arrangements differ in rural areas. The system of 'up-front' rental payment has not been adopted in such areas, and leases are generally three-year renewable contracts.

- Various taxes apply when leases are transferred in the secondary market (see Table 4 below). They conceptually represent efforts to capture capital gains on state land holdings (without having to sell the land to do so). Also, transfers have to be approved, meaning the state retains powers to control who 'owns' property.

Source: Alterman (2002a).

Plans to decentralise planning through reform of the ILA should be pursued more vigorously, but not without due regard for checks and balances. The Land Reform Bill laid the groundwork for substantial structural reform that would replace the ILA with a new body operating in a system of faster and lighter planning and administrative processes. The reform also envisages decentralisation of detailed planning to 
municipalities and property developers. However, at the time of writing, little progress in implementation had been made. Also, concerns have been raised that the proposals do not specify appropriate safeguards for planning at the municipal level (Bank of Israel, 2010).

In parallel to these reforms, the authorities have taken special steps to speed up the approval of housing construction as part of their efforts to cool the market. These have initially involved speeding up planning and approval processes within the regular planning system. This has already had some impact. Construction activity has increased markedly since 2009, with housing starts now above the rate of household formation (there are roughly 39000 new households per year). It is estimated there will be 44000 housing starts by the end of 2011, which is an increase on the 2010 figure and the highest number since the early 2000s (Figure 1, Panel F). In addition, as of December 2010, farmers have been given incentives encouraging them to give up leases on land that has been approved for residential construction. This programme will potentially unblock the development of up to 12000 new dwellings. And, in 2011 new legislation (the National Housing Commissions Law) has been passed establishing a temporary planning process based on new district-level committees that are responsible for the entire residential housing planning process. The goal is to expedite the approval of development projects for 113000 new dwellings. But, care should be taken that this process contains adequate precautions so as to avoid construction projects that are regretted in the longer term.

The greater number of housing starts has increased demand for construction workers. According to data from the Central Bureau of Statistics in 2010 there were 192000 employees in the construction sector (of which 157000 were Israelis), compared with 178000 in 2009 (of which 147000 Israelis), an increase of about $8 \%$. However, so far at least, official data do not indicate exceptionally strong increases in wages, which would suggest that the authorities should not bow to industry pressures to cancel reductions in the quotas for foreign workers (see OECD, 2011b), for an in-depth account of foreign workers in Israel).

\section{Policies affecting purchase, ownership and sale}

Various policies affect the process of buying, owning and selling property and often strongly influence whether households decide to purchase or rent. Therefore, these policies can affect price developments in the housing market, households' consumption and investment behaviour and the scale and nature of household credit supplied by the financial sector. This section deals with general regulations and policies. Targeted mortgage and rental support is discussed in later sections.

\section{Regulation of housing credit: powerful policy tools governing mortgage lending}

Mortgage regulation has long disciplined lending behaviour by banks by encouraging relatively low loan-to-value ratios (LTVs). This is principally achieved via loan-loss provisions, i.e. minimum amounts that banks must put aside to cover potential losses. The provisions are set such that the profitability of loans above certain LTVs is significantly reduced. Prior to recent moves to cool the housing market (see below), the provisions strongly discouraged LTVs of more than 70\%. Additional loan-loss provisions are imposed on mortgages if repayments are in arrears, thus providing an additional disincentive to imprudent lending.

In other respects mortgage regulation (at least historically) has been relatively unobtrusive. For instance, (as is usually the case elsewhere) there are no regulations regarding the size of mortgage repayments in relation to income. Also, banks have had, until recently, a free hand in the type of mortgage that is sold. In practice, CPI-indexed mortgages, typically with 20-year terms (with either fixed or floating interest rates), have previously been the most common products. However, the low market interest rates prompted by the 2008-09 downturn generated a wave of demand for non-indexed mortgages with floating 
rates that closely track the Bank of Israel's policy rate. Indeed, in 2010 about half the number of new mortgages were of this form (Bank of Israel, 2011).

Mortgage regulation has been tightened as part of the set of measures to cool the housing market in light of the recent surge in prices. The first step was taken in June 2010 with an increase in loan-loss provisions for mortgages with LTVs above $60 \%$ (Table 3). Loan-loss provisions were later increased for larger loans, and most recently new minimum loan-loss provisions for all mortgages were introduced. In addition, reporting requirements have been increased. As from May 2011, the share of the variable-interest component in any individual new mortgage can no longer exceed one-third.

\section{Table 3. Recent changes to mortgage regulations}

\begin{tabular}{ll}
\hline \multicolumn{1}{c}{ Regulatory issue } & \multicolumn{1}{c}{ Detail } \\
\hline $\begin{array}{l}\text { Loan-loss provisions } \\
\text { (May 2010) }\end{array}$ & $\begin{array}{l}\text { Draft guidelines published advising banks to include an additional safety net provision } \\
\text { of } 0.75 \% \text { of the value of the loan when the LTV is high. }\end{array}$ \\
$\begin{array}{l}\text { Mortgage rules on } \\
\text { "purchase groups" } \\
\text { (July 2010) }\end{array}$ & $\begin{array}{l}\text { Credit extended by banks to purchase groups buying more than ten units for construction has } \\
\text { to be classified as credit to property developers, rather than mortgage credit. }\end{array}$ \\
$\begin{array}{l}\text { Reporting requirements } \\
\text { (July 2010) }\end{array}$ & $\begin{array}{l}\text { Reporting requirements on mortgage lending increased. These now include information on the } \\
\text { type of mortgage holder, the value of the asset, the proportion financed, outstanding balances } \\
\text { and arrears on repayments. }\end{array}$ \\
\hline $\begin{array}{l}\text { Loan-loss provisions } \\
\text { (October 2010) }\end{array}$ & $\begin{array}{l}\text { Increased minimum loan-loss provisions stipulated on loans of more than NIS } 800 \text { 000 in } \\
\text { which the LTV is at least } 60 \% \text { and where the mortgage includes at least one quarter } \\
\text { floating-interest component. }\end{array}$ \\
\hline $\begin{array}{l}\text { Size of variable-interest } \\
\text { component (May 2011) }\end{array}$ & $\begin{array}{l}\text { Variable-interest component of new mortgages limited to one-third of the total value of the } \\
\text { mortgage. }\end{array}$ \\
\hline $\begin{array}{l}\text { Loan-loss provisions } \\
\text { (May 2011) }\end{array}$ & $\begin{array}{l}\text { New minimum loan-loss provisions introduced for all new mortgages. Loan-loss provisions for } \\
\text { mortgage arrears also tightened. }\end{array}$ \\
\hline
\end{tabular}

Source: Bank of Israel.

There is a risk that tighter mortgage regulation is prompting a rechanneling, rather than a reduction in housing credit. For instance, banks may have reacted by taking a more liberal view of applicants' financial commitments and indeed may have been ramping up non-mortgage lending to compensate for the tighter mortgage regulations. Under current reporting requirements, the authorities have little means to gauge and influence banks' assessment of credit worthiness for mortgages, including whether the sizeable deposit required for a mortgage is itself financed by some form of credit.

\section{Transactions costs are low}

Transactions fees and taxes at the point of house purchase are admirably light (Figure 6). When such charges are high, then house-price volatility may be reduced, but this benefit is probably outweighed by the adverse effect of high transactions fees on residential mobility (Andrews et al., 2011). In Israel, there is only one special tax imposed on purchase (Mas Rechisa), and private purchases of primary residences up to a certain value are exempt (Table 4). As part of a number of measures to discourage so-called purchase groups, a legal loophole that had allowed them not to pay VAT on the cost of construction was closed in January 2011. Also, as of February 2011 the purchase tax has been temporarily raised for those buying for investment purposes; the higher rates will apply in 2011 and 2012. 
Figure 6. International comparison of transaction costs in house purchase 2009

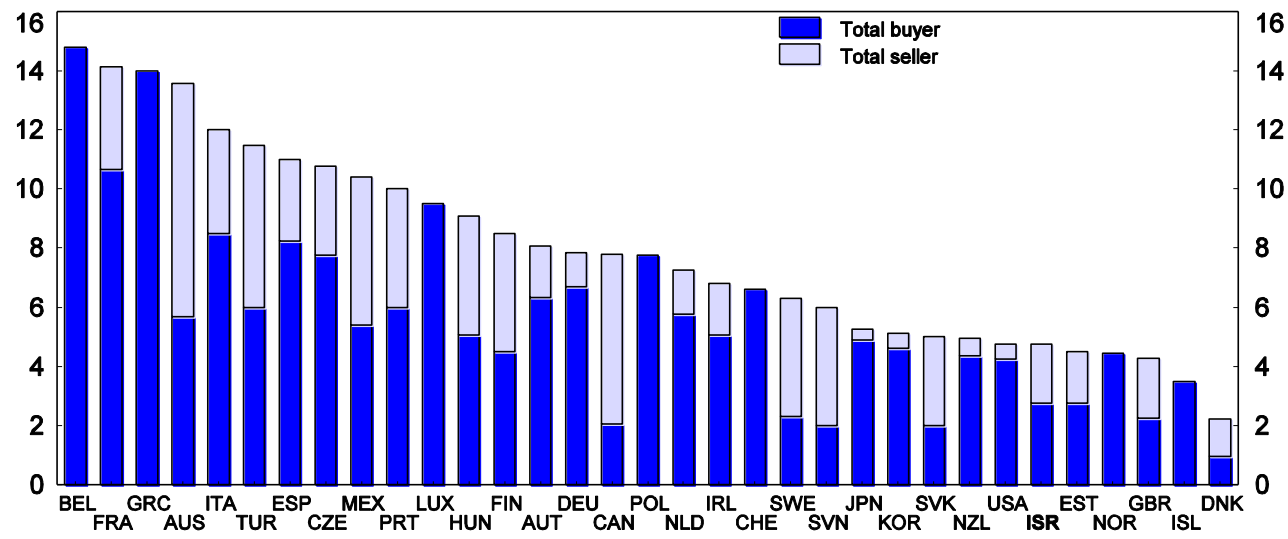

Source: Johansson, Å. (2011), "Housing Policies in OECD Countries: Survey-based Data and Implications", OECD EConomics Department Working Papers, No. 836.

Table 4. Taxes and fees relating to house purchase

\section{Type of tax}

Detail

Transaction fees and taxes at time of purchase

Mandatory insurance for property under construction

Purchase tax (Mas Rechisa)

Sales tax (Mas Mechira) (terminated in 2007)

\section{Tax issues during ownership}

Tax treatment of mortgages

Municipal Tax (Arnona)

Tax treatment of rental income

\section{Tax treatment on sale of property}

Capital gains tax (Mas Shevach)

Income tax

Land Betterment Tax (Hetel Hashbacha)
Contractors must arrange insurance on payments for property under construction (the cost of the insurance usually borne by the buyer).

For primary residences there is an exemption from purchase tax for properties up to a certain value (currently NIS 1.35 million); above this value the rate ranges between 3.5 and $5 \%$. For non-primary residences the tax has temporarily been increased and ranges between $5 \%$ and $7 \%$ of the property value (previously it ranged from $3.5 \%$ to $5 \%$ ).

This tax was $2.5 \%$ on the sale of residential property as a business $(0.8 \%$ in the case of building contractors selling property).

No tax relief on mortgage interest payments, but also no account of implicit rental income from owner-occupancy in taxable income.

Paid by the end-user and based on surface area and type of property.

Rental income accruing to businesses is subject to corporation tax while that accruing to households is partially exempt in the case of residential properties (rental income from commercial properties is taxed at the owner's personal or corporate tax rate).

Based on past inflation and a number of special allowances. Private households with only one residential property are exempt as long it has been held for at least 18 months. Additional properties are also exempt as long as they are held for at least four years. As part of efforts to boost the supply of housing, as from January 2011 those owning a second home have been exempted from the tax as long as the home is sold in 2011 or 2012. However, from 2013 onwards the minimum holding period will increase to eight years and some other exemptions will be terminated.

The rate of tax was reduced from $45 \%$ to $20 \%$ in 2000 , but the reduction was grandfathered, i.e. sellers were charged a rate reflecting the proportion of their tenure spent at the $45 \%$ rate. A recent reform removed the grandfathering, i.e. all sellers are now charged $20 \%$.

Contractors and developers that sell real estate pay income tax instead of capital gains tax on the sale of such property.

This is a municipal tax paid upon sale of investment property that has benefited from an increase in value due to a land-use zoning change or the approval of additional building rights. The tax is $20 \%$ of the calculated real betterment accrued during ownership. Exemption from the tax is allowed for build-and-vacate projects and for improvements strengthening structures against earthquakes. 


\section{Acceptable compromise in tax treatment during ownership}

The tax treatment during ownership of housing assets follows a reasonable 'second-best' approach. Ideally owner-occupiers would be taxed on their imputed rental income but allowed to deduct mortgage-interest payments. However, in most countries, including Israel, implicit rents are not taxed because of the challenges and potential controversies in their calculation. At the same time, and similar to some other countries, households cannot deduct mortgage interest from taxable income, which partially compensates for the failure to tax implicit rents. ${ }^{5}$

Property taxation is more extensive in Israel than in many other OECD economies but nevertheless could be exploited further. The tax (Arnona) is based on the surface area and type of property and is a significant source of revenues for municipalities. Indeed, revenues are equivalent to $2.5 \%$ of GDP; in most OECD countries such revenues are less than 1\% of GDP (Figure 7). In broad terms this is welcome, given the low risk of evasion, less distortionary effects on economic behaviour compared with other tax bases, and reasonable progressivity. However, there are often shortfalls in revenue collection in poorer municipalities, which contribute to their financial difficulties and widen the differences in local tax revenues across jurisdictions. Unless solutions to this can be found then making greater use of the Arnona as a source of revenue will be problematic.

The tax treatment of rental income makes it relatively attractive for private households to own and rent out properties. While rental income accruing to business entities is subject to corporate tax, private households, up to certain limits, do not have to declare such income. These exemptions should be reconsidered so as to put property ownership on a more equal footing with other assets.

\section{Figure 7. International comparison of recurrent taxes on property}

As a share of GDP, $2009^{1}$

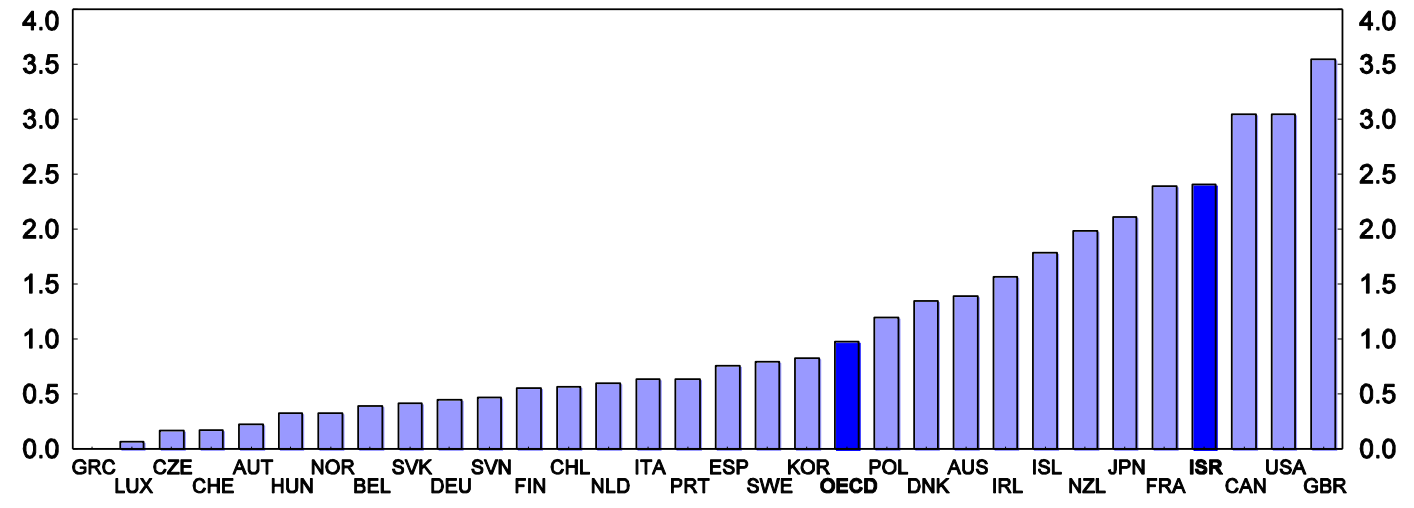

1. Or latest available year.

Source: OECD.stat, Tax Revenue Statistics database.

\section{Excessively generous tax exemptions in capital gains from property sale}

Exemptions from tax on capital gains from property sales (Mas Shevach) are unusually generous. As in many countries, private households do not pay capital gains tax on the sale of their principal residence.

5. For an international comparison of how the income tax and capital gains tax aspects of housing are treated see Cheung (2011). According to these data 13 OECD countries do not account for imputed rents and have tax relief on mortgage interest. 
However, under certain circumstances there are also exemptions on additional properties. This, combined with exemption of rental income, implies generous treatment for relatively affluent households that is likely to further distort the consumption/saving decision. A temporary additional exemption was granted as part of measures to cool the housing market (Table 4). This measure was understandable in light of the concerns about the effects of high house prices. But, for the longer term the authorities should look towards reducing the number of exemptions. Ideally, all exemptions should be removed; at a minimum, exemptions should be limited to the principal residence only. In 2011, some progress was made on this front, notably with the increase in the minimum holding period for exemption from capital gains tax on non-primary housing from four to eight years (Table 4).

There is an additional form of capital gain tax, the Land Betterment Tax (Hetel Hashbacha) which is a municipal tax imposed when leases are sold on the open market if the land associated with the lease has been reclassified (re-zoned) and consequently increased in value during the current leaseholder's tenure. It is effectively a mechanism to capture some of the windfall gains in land values generated from approval of land for property development, without having to actually sell the land. Consideration should be given to raising the tax rate, so as to shore up the state's stake in windfall profits from re-zoning and reduce the incentives for property developers to try to influence planning decisions.

\section{Public support for housing}

Public support to housing in Israel reflects a number of motivations and agendas. A large share of spending goes towards helping recent permanent immigrants as part of Israel's wide-ranging support and integration measures. For instance, in $200951 \%$ of central-government housing support went either to general rent- and mortgage-subsidy schemes for immigrants or on special schemes for Ethiopian immigrants (Figure 8). Deeper investigation of eligibility criteria and benefits reveals other reasons for housing support. Notably, there is additional mortgage support for those in peripheral areas (Table 5). Regional incentives of this sort can be justified on economic grounds as countering negative externalities (e.g. congestion) arising from the gravitational economic pull of the central areas of the country. However, this is almost certainly not the sole motivation. Special consideration is also given to those who have completed military service, reflecting a wider range of benefits that is designed to encourage and motivate military and reserve service but which also effectively means differential treatment of Jewish and Arab communities.

Figure 8. Central-government spending on rent subsidies and support for house purchase

2009 outturn, total spending NIS 2.2 billon

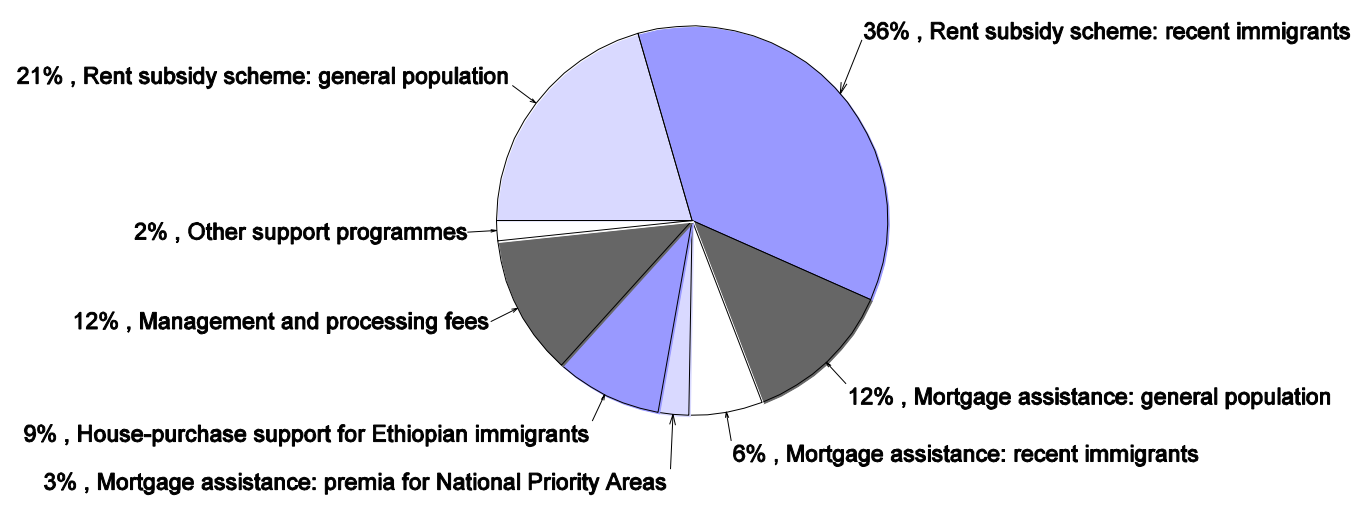

Source: Ministry of Construction and Housing budget 2009. 
ECO/WKP(2011)81

Table 5. Central-government housing-support schemes

\begin{tabular}{|c|c|c|}
\hline Scheme & Key eligibility conditions & Benefit amount \\
\hline Social housing & $\begin{array}{l}\text { - Families and single-parent families with at least three } \\
\text { children must either be receiving National Insurance } \\
\text { income support or have combined wage income below a } \\
\text { certain level (currently NIS } 5537 \text { ). In addition they must } \\
\text { have a score of at least } 1400 \text { in the points system (see } \\
\text { main text) } \\
\text { - Other households (except groups below) must pass a } \\
\text { different means test and have a score of at least } 1400 \text { on } \\
\text { the points system. } \\
\text { - Recent immigrants apply via a separate means test run by } \\
\text { the Ministry of Absorption. No points are required. } \\
\text { - Special conditions also apply for households with disabled } \\
\text { persons. }\end{array}$ & $\begin{array}{l}\text { Rents in tenancies given } \\
\text { since } 2005 \text { are based on } \\
\text { market rents less a discount } \\
\text { that varies according to family } \\
\text { composition and income. } \\
\text { Tenancies granted prior } \\
\text { to } 2005 \text { remain under a } \\
\text { previous system (this is only } \\
\text { relevant to those in receipt of } \\
\text { National Insurance income } \\
\text { support). Overall, the average } \\
\text { rent in social housing is } \\
\text { NIS } 277 \text { per month. }\end{array}$ \\
\hline $\begin{array}{l}\text { Rent subsidy } \\
\text { scheme }\end{array}$ & $\begin{array}{l}\text { Eligible groups comprise: } \\
\text { - Families (including single-parents) and couples without } \\
\text { children. Eligibility is based on family composition and } \\
\text { earnings. Where there is at least one disabled household } \\
\text { member, eligibility is based on receipt of National } \\
\text { Insurance income support. } \\
\text { - Single-persons aged } 55+\text { who receive National Insurance } \\
\text { and single disabled persons aged } 21+\text {. } \\
\text { - All immigrants are eligible for rent subsidies from the } \\
\text { second to the fifth year following arrival (assistance for the } \\
\text { first year is provided through the Ministry of Absorption). }\end{array}$ & $\begin{array}{l}\text { Benefit amounts vary } \\
\text { according to household } \\
\text { composition, location and } \\
\text { income level. } \\
\text { - Benefits are tapered beyond a } \\
\text { certain level of income. }\end{array}$ \\
\hline $\begin{array}{l}\text { General } \\
\text { mortgage } \\
\text { assistance }\end{array}$ & $\begin{array}{l}\text { - Limited to families (including single-parents) and couples } \\
\text { without children. } \\
\text { - The maximum loan possible depends on the score in the } \\
\text { points system, time spent in military service and location } \\
\text { (see Annex A1 for further detail). } \\
\text { - A separate system operates for households in kibbutzim. }\end{array}$ & $\begin{array}{l}\text { - Support guarantees a } \\
\text { maximum CPI-linked } \\
\text { mortgage rate of } 4 \% \text {. Thus, } \\
\text { subsidies are only triggered } \\
\text { when interest rates rise above } \\
\text { this threshold. } \\
\text { Since } 2008 \text { the support to } \\
\text { households scoring up } \\
\text { to } 1999 \text { on the points system } \\
\text { (or } 1699 \text { points for those } \\
\text { purchasing in a National } \\
\text { Priority Area) comprises } \\
\text { subsidies on regular bank } \\
\text { mortgages. Households with } \\
\text { point scores above these } \\
\text { levels are eligible for 'direct' } \\
\text { state-backed mortgages. }\end{array}$ \\
\hline $\begin{array}{l}\text { Other support } \\
\text { for home } \\
\text { purchase }\end{array}$ & $\begin{array}{l}\text { - Schemes promoting the purchase of public housing (the } \\
\text { latest scheme ended in } 2010 \text { and has not been replaced, } \\
\text { see Annex A1) } \\
\text { - Special system of grants and loan subsidies for new } \\
\text { Ethiopian immigrants. } \\
\text { - Loans/grants for house purchase and infrastructure in } 28 \\
\text { communities located in National Priority Area A regions } \\
\text { (see main text). }\end{array}$ & \\
\hline
\end{tabular}

In broad terms, the number of households receiving housing support has been declining for some time. The number of households in low-rent publicly owned dwellings has fallen dramatically largely due to schemes allowing the sale of such housing. In addition, the numbers of recipients of rent support and new entrants to mortgage-support schemes have fallen (Figure 9). This partly reflects downward trends in 
permanent immigration, tighter eligibility conditions and, in the case of mortgage support, weaker incentives to apply for schemes because of falls in mortgage rates on the open market.

Figure 9. Trends in the number of households receiving housing support

Thousands of households
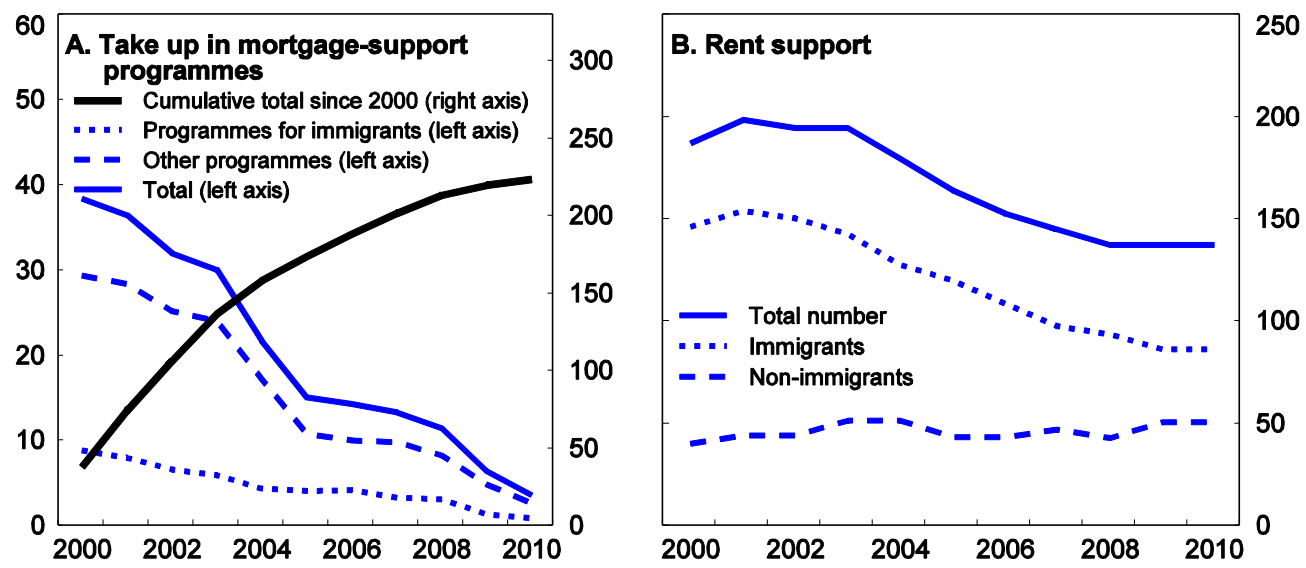

Source: Ministry of Construction and Housing.

\section{Rent subsidies are the most common form of regular housing support}

Cash subsidies to households renting in the private sector ("rent participation grants") are the most common form of housing support and account for a significant share of the Ministry of Construction and Housing's budget. In 2010, a little under 140 thousand households received rent subsidies (Figure 9), which is much lower than in the early 2000s due to falls in the number of immigrants. In fact, the number of non-immigrants receiving support has increased slightly over this period. The rent subsidies are provided to all immigrants, irrespective of income, for the first five years of settlement in Israel. This should be reformed, for instance with the introduction of a means test, so as to focus spending on immigrants in need. In contrast, consideration should be given to making regular means-tested rent support more generous as part of wider efforts to reduce poverty. Rent support can play a useful auxiliary role in tackling poverty, because it brings some differentiation in welfare support according to the cost of living (rent support is calculated in relation to local market rents; see Table 5). As such, raising the value of rent support may well be warranted along with increases in other welfare measures, but the increases need to be carefully calibrated using micro simulations to ensure that they dovetail with other welfare and tax measures. In addition, some caution would be required because hikes in rent support may get passed through into increases in market rents.

\section{Rental regulation may be too light}

Rental regulation is very light in international comparison. There are no rules governing the level or rate of increase in rents, which is welcome. However, this liberal approach extends to all aspects of the rental contract to a degree that may not be optimal. Rental contracts are governed only by general legislation applying to movable and immovable property (the Hire and Loan Law, 1971). Hence, neither landlords nor tenants are protected by the type of specialised legislation on the rental of dwellings that can be found in other OECD countries, such as minimum notice periods and regulations on deposits. According to data compiled in a recent OECD study (Andrews et al., 2011), Israel has the second lowest score in an indicator of landlord-tenant regulations (Figure 10). To be sure, such regulation can be too burdensome and lead to a thin market. Also, Israeli rental contracts drawn up between landlord and tenants 
typically do feature clauses on notice periods and so on. Nevertheless, some modest universal legislated criteria should be considered as a means of strengthening legal protection on both sides of the contract and encouraging the development of the rental market by setting some basic ground rules.

\section{Figure 10. Tenant-landlord regulations in the private rental market, ${ }^{1} 2009$}

Scale 0-6: Increasing in protection for tenants

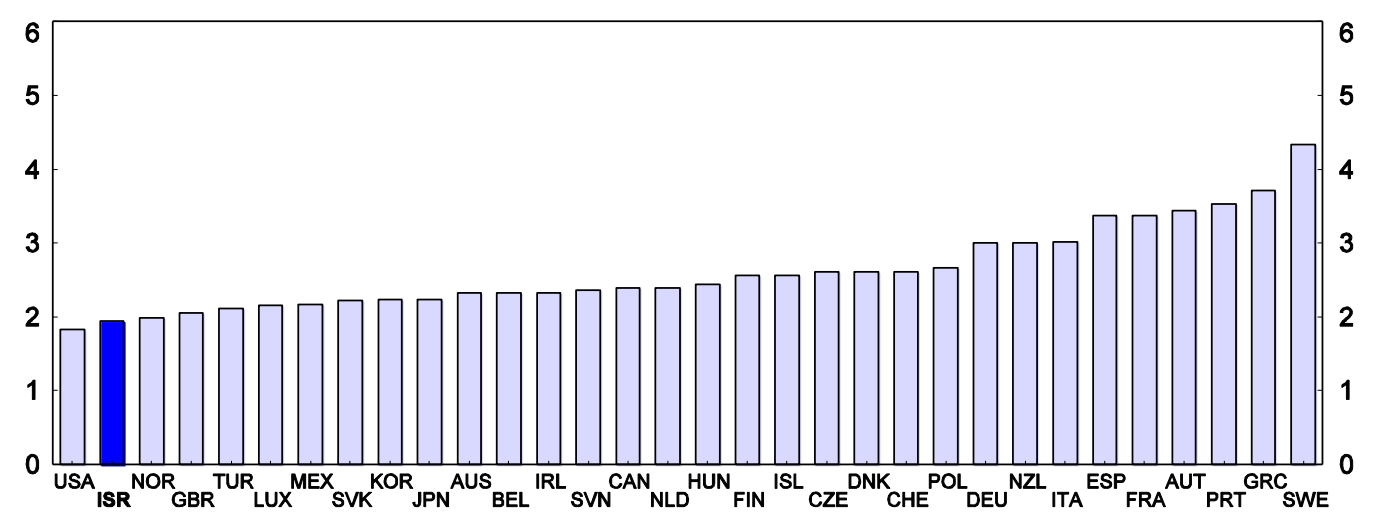

1. The indicator measures the extent of tenant-landlord regulation within a tenancy. It includes the ease of evicting a tenant, degree of tenure security and deposit requirements. See Johansson (2011) for details.

Source: Johansson, Å. (2011), "Housing Policies in OECD Countries: Survey-based Data and Implications", OECD EConomics Department Working Papers, No. 836.

\section{Access to public housing should be more uniform}

Public housing is now on a relatively small scale in Israel, but it provides generous levels of support for those who are eligible. In 2010 there were around 65000 publicly owned dwellings, a fairly small number against about 2.1 million households. This is partly the effect of a succession of schemes promoting the sale of public housing to residents. Between 1999 and 2010 some 33000 dwellings were sold through schemes offering a combination of discounts on the sale price and mortgages at preferential rates (see Annex A1). The implicit value of support is substantial: the average rent in public housing is only NIS 277 per month, which is equivalent to USD 77 and much lower than market rents (according to official data, these averaged NIS 3104 per month in the second quarter of 2011, for instance).

Access to public housing has several tracks (Table 5), most notably for the general population the eligibility criteria differ, depending on whether the households has at least three children or not. All groups have to pass some form of means test. In addition, access to public housing for non-immigrants is narrowed further by a somewhat unusual points system (this also features in mortgage assistance; see below). A score of at least 1400 points is required and is based on: years of entitlement (this is either the number years of marriage or the number of years the applicant is aged over 30), number of children and how many siblings the adult members of the household have (see Table 6). Awarding points for siblings is unusual. It implies, for instance, a couple married for five years (worth 450 points) with three children (500 points) will pass the points test for public housing if they have at least five brothers and sisters (600 points), but not if they have four or less siblings (400 points). According to the Israeli authorities, the points for siblings reflect the fact that parents often help children with housing costs: thus children from large families are likely to receive less parental support than others.

The eligibility system should be made more uniform and simpler. At a minimum the distinction between households based on whether there are three (or more) children should be removed. Awarding points for siblings is likely to be a very inaccurate measure of whether a household has access to parental 
support and is therefore probably granting access to public housing for some and not to others in a somewhat arbitrary way. This dimension of the points system should be scrapped. In addition, as for rental support, the presence of a separate track for recent immigrants is questionable.

Table 6. The points system used to gauge eligibility for public housing and mortgage assistance

\begin{tabular}{cccc}
\hline Value & Years of entitlement & No. of children & No. of siblings ${ }^{1}$ \\
\hline 1 & 30 & 0 & 0 \\
2 & 250 & 350 & 50 \\
3 & 300 & 500 & 100 \\
4 & 400 & 800 & 400 \\
5 & 450 & 900 & 600 \\
6 & 500 & 1000 & 650 \\
Each additional & 50 & 100 & 50 \\
\hline
\end{tabular}

1. Siblings are limited to family members who are resident in Israel.

Source: Ministry of Construction and Housing, Senior Deputy Director General's Office for Housing Assistance.

\section{Until recently subsidised home purchase was on the wane}

The substantial fall in support for house purchase in recent years is welcome. In the 1990s, there was fairly substantial subsidisation through direct grants for home purchases and mortgages under preferential conditions. Direct grants are now available only to Ethiopian immigrants. Mortgage support comprises a scheme available to the general public and (until recently) targeted schemes promoting the sale of public housing and measures for immigrants. Until 2011 take-up of programmes had fallen steadily. In 2000, around 38000 new preferential-rate mortgages were granted, but by 2009 this figure had fallen to around 2500 , partly reflecting tighter eligibility rules. In addition, the guaranteed maximum interest rate of $4 \%$ (CPI-indexed) has become less attractive in recent times due to falls in mortgage rates available on the open market (see Figure 2, Panel B).

Unlike rent support and public housing, the general scheme of mortgage support does not entail direct means tests and is therefore potentially accessible for households with substantial incomes. Eligibility and the (maximum) size of mortgage provided depends on: the household's score in the points system (Table 6), length of military service and the location of the dwelling attached to the mortgage (see Annex A1 for further details). For example, households scoring less than 1400 points in the points system and with no premium for military service or location are eligible for a mortgage up to NIS 62400 (about USD 17300 at an exchange rate of 3.6), while a household with at least 2200 points and the maximum premium for military service located in a National Priority Area (see Box 2) can be eligible for a mortgage of up to NIS 356000 (approximately USD 98 850) (Figure 11). Although relatively few households currently access the scheme, the absence of any limit on household income for eligibility should be addressed.

In 2011 a new programme began, signalling a willingness to resume highly targeted mortgage support. The scheme targets 28 designated communities in National Priority Areas and was established following strong pressure from politicians representing certain communities. It provides support of up to NIS 100000 for the purchase of homes and targets young families (one of the eligibility conditions is that applicants must not already own a home). The support is initially in the form of a loan but is converted to a grant (i.e. the loan is written off) as long as the household remains resident for at least five years. The scheme also provides subsidies to builders for the construction of related infrastructure. According to the government, the scheme will prompt 4000 new housing starts per year. As with all such forms of support for house purchase, there is a risk that the subsidies will prompt increases in house prices and therefore be 
at least partially captured by existing homeowners and property developers, rather than the young families for whom it was intended.

\section{Figure 11. Examples of mortgages available under the general mortgage assistance scheme}

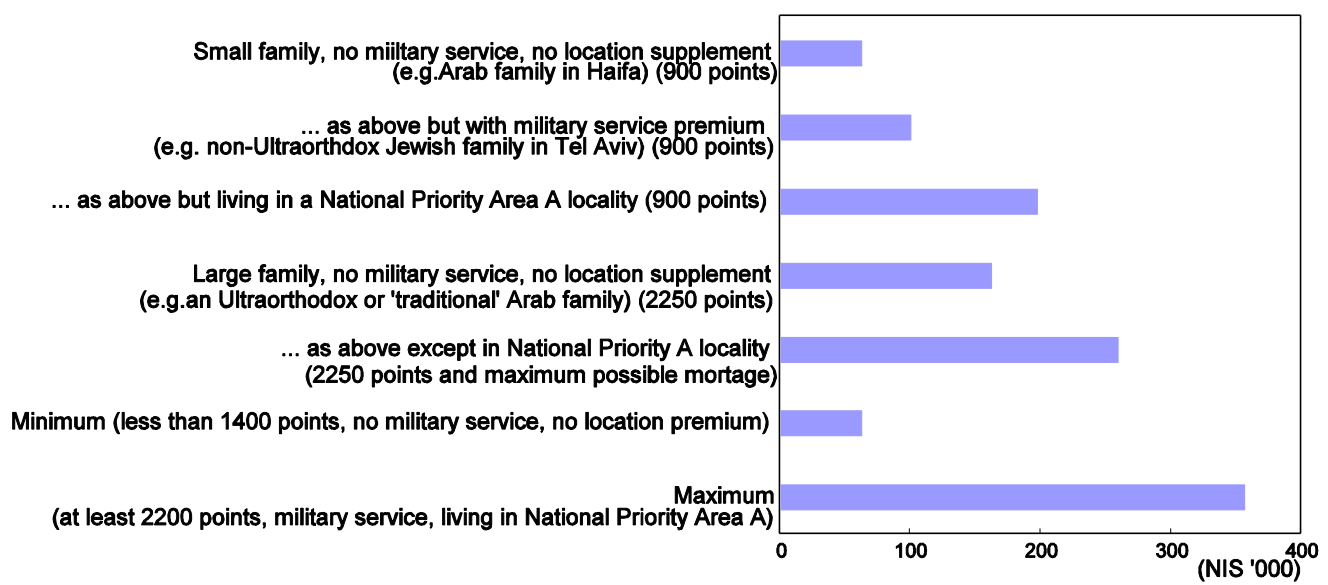

Source: OECD calculation based on data from the Ministry of Construction and Housing, Senior Deputy Director General's Office for Housing Assistance.

\section{Box 2. National Priority Areas}

National Priority Areas were first established in 1998 under Government decision No. 3292, which established Class A and Class B areas, with the former receiving greater support than the latter. Legislation adopted in 2002 (Government decision 2288) re-defined the boundaries, but this prompted a court case, and in February 2006 the High Court determined that the legislation was unlawful, in particular because it discriminated against Arab localities. The Court stated that its verdict should be applied within one year, (i.e. by February 2007) and stressed that if new legislation was introduced it must not grant the government or its ministers general and sweeping powers in regard to the classification of localities as NPAs and the granting of benefits and increased budgets to these localities. However, the verdict was never applied, and the 2002 legislation remained operational until recently. Efforts to replace the 2002 legislation began in July 2009 when the Knesset passed the Economic Efficiency Bill, which included a generally worded statute that gives the government wide discretion in classifying localities and areas as National Priority Areas and distributing benefits to them in various domains and for various periods of time.

In December 2009, based on the powers vested by the new law, the government approved Decision No. 1060, which proposes a common map of NPAs for use in the following policy areas: housing and urban development, education, employment promotion, public infrastructure, and culture and sport. Shortly afterwards an amendment added some types of support for agriculture to this list. Therefore, in principle, the vast majority of central-government support schemes involving geographic criteria now operate under the same boundary system. Four selection criteria were applied in determining the new NPAs. Two criteria define geographic areas of security and strategic interest, some of which are beyond the scope of OECD analysis, while the remaining two comprise:

- Localities based on an index combining social-economic characteristics and a measure of spatial "distance" from Tel Aviv was used to score sub-districts with those receiving the lowest scores being classified as NPAs (up to a coverage of $25 \%$ of the population). Predictably, these NPAs are found in northern and southern areas with a high proportion of Arab communities.

- "New localities", which are included on the grounds that when communities are first established, their inhabitants contend with issues of bureaucracy, unfinished infrastructure and economic burdens that stem from a small population size. 


\section{Affordable housing schemes are underway}

In July 2011 the central government announced two plans for affordable housing, involving more indirect support mechanisms than regular housing support. One scheme aims to encourage the expansion of rental accommodation. The plan is to release land for property development with tender conditions that a certain share of the apartments (probably between 20 and 40\%) are rented out on a long-term basis. These property developments will (unlike regular releases) not be subject to a minimum tender offer. The authorities would retain control over who is offered this type of accommodation, but the eligibility conditions have yet to be decided. The Trajtenberg Committee (see Assessment and recommendations) recommended allocating these dwellings to ensure that they are available only to households with wage earners and not to existing homeowners or those with incomes in the top four deciles. The Committee also recommended some additional steps to encourage rentals; for instance it recommended tax breaks to institutional funds (or other financial entities) for investment in rental property.

The other central-government affordable-housing scheme aims to use an existing reverse-auction process to provide low-cost housing for home buyers. Since 1994, several thousand housing units marketed by the ILA each year have been released using a tender process in which the leasehold price of land is set in advance (usually the tenders are awarded on the basis of the leasehold price). Those tendering for the contracts (i.e. property developers) then compete on the sale price of the completed dwellings. In the past, the leasehold price has been set according to an assessment of the market price. It has been proposed to discount the leasehold price by 50\% (up to a maximum of NIS 150000 per unit).

In addition, some large municipalities, in particular Tel Aviv and Jerusalem, have independently elaborated plans for affordable housing (for rent but also for purchase), but these initiatives have encountered a legal barrier that is yet to be resolved.

\section{Box 3. Recommendations for improving economic policy in the housing market}

\section{Housing construction}

- Pare back central-government's role in property development. Pursue plans to decentralise planning through permanent reforms to the ILA and planning processes. However, do not excessively override planning and consultation processes.

- $\quad$ Allow more dwelling leaseholders to convert to full legal ownership.

House purchase, household finances during ownership and the sale of property

- Counter evasive action by banks that circumvents and dilutes mortgage regulation.

- Prune exemptions from capital gains taxation on property sales and rental income received by private households.

- $\quad$ Consider making greater use of property taxation (Arnona).

\section{Housing support}

- In broad terms aim for a simpler and more transparent system of housing support. In addition:

- Ensure rent support dovetails with other aspects of the tax-benefit system for low income households. Consider raising rent subsidies as part of wider efforts to reduce poverty. Reconsider the provision of universal rent support to recent immigrants.

- Make eligibility for social housing more uniform across households. Do not grant points for siblings in the points system.

- Scale back support for home purchase, for instance by introducing income criteria for access to general mortgage support.

- Introduce modest minimum criteria in rental contracts such that both landlords and tenants are more assured of their rights and responsibilities. 


\section{Bibliography}

Alterman, R. (2002a), "The Land of Leaseholders; Israel's Extensive Public Land Ownership in an Era of Privatization", in S.C. Bourassa and Y. Hong (eds.), Leasing Public Land: Policy Debates and International Experiences, Cambridge, Massachusetts, Lincoln Institute of Land Policy.

Alterman, R. (2002b), "Strategies for Immigrant Absorption: Learning from the Israeli Experience", Research report prepared for the World Bank West Bank and Gaza Department.

Andrews, D., A. Caldera-Sanchez and A. Johansson (2011), "Housing market policies and structural policies in OECD countries", OECD Economics Department Working Papers, No. 836.

Andrews, D. and A. Caldera-Sanchez (2011), "Drivers of homeownership rates in selected OECD countries", OECD Economics Department Working Papers, No. 849.

Bank of Israel (2010), Bank of Israel Annual Report, 2009, Jerusalem.

Bank of Israel (2011), Bank of Israel Annual Report, 2010, Jerusalem.

Benchetrit, G. and D. Czamanski (2009), "Immigration and Home Ownership: Government Subsidies and Wealth Distribution Effects in Israel", Housing, Theory and Society, Vol. 26, No. 3.

Caldera-Sanchez, A. and D. Andrews (2011), "To Move or Not to Move: What Drives Residential Mobility Rates in the OECD?", OECD Economics Department Working Papers, No 846, Paris.

Catte, P., N. Girouard, R. Price and C. André (2004), "Housing Markets, Wealth and the Business Cycle", OECD Economics Department Working Papers, No. 394, Paris.

Cheung, C. (2011), "Policies to Rebalance Housing Markets in New Zealand", OECD Economics Department Working Papers, No. 878, Paris.

Haider, A. (ed.) (2008), The Equality Index of Jewish and Arab Citizens in Israel, The Sikkuy Report 2008.

IMF (2008), World Economic Outlook: Housing and the Business Cycle, World Economic and Financial Surveys, IMF.

OECD (2004), OECD Economic Outlook, No. 75, June, OECD Publishing, Paris.

OECD (2010a), OECD Economic Reviews of Labour Market and Social Policies, Israel, OECD Publishing, Paris.

OECD (2010b), Economic Survey of Israel, OECD Publishing, Paris.

OECD (2011a), Study on the Geographic Coverage of Israeli Data, OECD Publishing, Paris.

OECD (2011b), International Migration Outlook, OECD Publishing, Paris.

Sayag, D. (2011), "Measuring Local House Price Movements in Israel and Estimating Price Elasticity", Paper presented at the $12^{\text {th }}$ Conference of the International Working Group on Price Indices, Wellington, New Zealand. 


\section{Annex Al}

\section{Additional details on housing support}

\section{Additional details on the general mortgage assistance scheme}

Size of mortgages available

\begin{tabular}{cc}
\hline Points & Size of 25/28-year mortgage loan (4\%) \\
\hline Up to 1399 & 62400 \\
$1400-1499$ & 74350 \\
$1500-1599$ & 85250 \\
$1600-1699$ & 96190 \\
$1700-1799$ & 107090 \\
$1800-1899$ & 117985 \\
$1900-1999$ & 128930 \\
$2000-2099$ & 139825 \\
$2100-2199$ & 150720 \\
$2200+$ & 161665 \\
\hline
\end{tabular}

Source: Ministry of Construction and Housing, Senior Deputy Director General's Office for Housing Assistance.

\section{Military service premia}

Supplement of 1 percentage point on the mortgage loan for each month of military service with a maximum supplement of $60 \%$ per couple. Therefore, a couple who both complete regular military conscription (three years for men and two years for women) will typically qualify for the maximum supplement.

Supplements for mortgages on dwellings in the "periphery" (2011 values)

\section{Supplement to mortgage assistance}

National Priority Area A

National Priority Area B

"Confrontation line localities"

"Confrontation line localities" in the north of Israel

Negev localities
NIS 97200 (half of this for individuals)

NIS 67200 (half of this for individuals), but only in for high-density buildings (i.e. apartments) NIS 38400 (toward the purchase of new dwellings)

NIS 38400 plus NIS 9500 grant (toward purchase of new dwellings, the additional grant is to cover the cost of secure space in the dwelling)

Ranges from NIS 48000 to NIS 84000 depending on location

Source: Ministry of Construction and Housing, Senior Deputy Director General's Office for Housing Assistance. 
ECO/WKP(2011)81

Programmes promoting the sale of public housing

\begin{tabular}{|c|c|c|c|c|}
\hline Programme & "My Home" & $\begin{array}{l}\text { "Buy Your } \\
\text { Home" }\end{array}$ & “Here's My Home" & $\begin{array}{c}\text { "An Apartment of } \\
\text { My Own }\end{array}$ \\
\hline Period & $\begin{array}{l}\text { February 1999- } \\
\text { April } 2000\end{array}$ & $\begin{array}{l}\text { April 2000- } \\
\text { December } 2004\end{array}$ & $\begin{array}{l}\text { April 2005- } \\
\text { December } 2009\end{array}$ & $\begin{array}{l}\text { September 2008- } \\
\text { December } 2010\end{array}$ \\
\hline $\begin{array}{l}\text { Minimum } \\
\text { occupancy of } \\
\text { dwelling }\end{array}$ & 5 years & 12 years & $\begin{array}{l}4 \text { years in National } \\
\text { Priority Areas, } \\
6 \text { years elsewhere. } \\
\text { From February 2007: } \\
2 \text { and } 3 \text { years, } \\
\text { respectively }\end{array}$ & 5 years \\
\hline $\begin{array}{l}\text { Parameters in } \\
\text { setting discount }\end{array}$ & $\begin{array}{l}\text { Longevity, number } \\
\text { of persons in } \\
\text { household }\end{array}$ & $\begin{array}{l}\text { Length of tenancy } \\
\text { ( } 3 \% \text { discount for } \\
\text { each year of } \\
\text { occupancy). }\end{array}$ & $\begin{array}{l}\text { Marital status and } \\
\text { place of residence }\end{array}$ & $\begin{array}{l}\text { Length of tenancy, } \\
\text { family composition, } \\
\text { location, type of } \\
\text { property }\end{array}$ \\
\hline $\begin{array}{l}\text { Maximum possible } \\
\text { discount }\end{array}$ & $\begin{array}{l}75 \% \text { of market } \\
\text { price, up to } \\
\text { NIS } 400000\end{array}$ & $\begin{array}{l}90 \% \text { of price up to } \\
\text { NIS } 600000\end{array}$ & $\begin{array}{l}85 \% \text { of price up to } \\
\text { NIS } 795000(92 \% \\
\text { from February } 2007)\end{array}$ & $\begin{array}{l}90 \% \text { of price in NPAs, } \\
82.5 \% \text { elsewhere, up } \\
\text { to NIS } 705000\end{array}$ \\
\hline $\begin{array}{l}\text { Mortgage-loan } \\
\text { subsidy }\end{array}$ & $\begin{array}{l}5 \% \text { fixed rate for } \\
3 \text { years }\end{array}$ & $\begin{array}{l}4.5 \% \text { fixed rate for } \\
12 \text { years }\end{array}$ & $\begin{array}{l}\text { Up to NIS } 150000 \\
\text { for } 20 \text { years at up to } \\
5 \% \text { interest }\end{array}$ & $\begin{array}{l}\text { Up to NIS } 150000 \text { at } \\
\text { up to } 5 \% \text { interest for } \\
15 \text { years }\end{array}$ \\
\hline Remarks & $\begin{array}{l}\text { Supplemental rent } \\
\text { in Priority Areas } \\
\text { and distressed } \\
\text { neighbourhoods }\end{array}$ & $\begin{array}{l}\text { Discounts } \\
\text { reduced at end of } \\
2003\end{array}$ & $\begin{array}{l}\text { Rules of scheme } \\
\text { revised in } \\
\text { February } 2007\end{array}$ & \\
\hline $\begin{array}{l}\text { No. of dwellings } \\
\text { sold as of end } \\
\text { September } 2010\end{array}$ & 3800 & 16070 & 10030 & 3500 \\
\hline
\end{tabular}

Source: Ministry of Construction and Housing, Information and Economic Analysis Division. 
ECO/WKP(2011)81

\section{WORKING PAPERS}

The full series of Economics Department Working Papers can be consulted at www.oecd.org/eco/workingpapers/

911. Fiscal prospects and reforms in India

(December 2011) by Richard Herd, Sam Hill and Vincent Koen

910. Structural reforms to reduce unemployment and restore competitiveness in Ireland

(December 2011) by Álvaro Pina

909. Getting back on track: restoring fiscal sustainability in Ireland

(December 2011) by David Haugh

908. A welfare analysis of climate change mitigation policies

(November 2011) by Alain de Serres and Fabrice Murtin

907. Overcoming the banking crisis in Ireland

(November 2011) by Muge Adalet McGowan

906. Macroeconomic and structural policies to further stabilise the Mexican economy

(November 2011) by Cyrille Schwellnus

905. Reaping the benefits of a transition to greener growth in Slovakia

(November 2011) by Caroline Klein

$904 \quad$ Fiscal reform for a stronger fairer and cleaner Mexican economy

(October 2011) by Nicola Brandt and Rodrigo Paillacar

903 The demand for safe assets in emerging economies and global unbalances: new empirical evidence (October 2011) by Rudiger Ahrend and Cyrille Schwellnus

902. Drivers of systemic banking crises: the role of bank-balance-sheet contagion and financial account structure

(October 2011) by Rudiger Ahrend and Antoine Goujard

901 Explaining the appreciation of the Brazilian Real

(October 2011) by Annabelle Mourougane

$900 \quad$ Raising investment in Brazil

(October 2011) by Jens Arnold

899 Refining macroeconomic policies to sustain growth in Brazil

(October 2011) by Annabelle Mourougane

898. Promoting infrastructure development in Brazil

(October 2011) by Annabelle Mourougane and Mauro Pisu

897. Austria: public sector inefficiencies have become less affordable

(October 2011) by Karin Fischer, Rauf Gönenç and Robert Price 
896. Informality in Mexico

(September 2011) by Nicola Brandt

895. Reforming Austria's highly regarded but costly health system

(September 2011) by Rauf Gönenç, Maria. M. Hofmarcher, Andreas Wörgötter

894 Greener growth in the Belgian federation

(September 2011) by Tomasz Koźluk

893. Green growth and climate change policies in New Zealand

(September 2011) by Alexandra Bibbee

892. Has deregulation increased investment in infrastructure? Firm-level evidence from OECD countries

(September 2011) by Sónia Araújo

891. Ensuring a Sustainable and Efficient Fishery in Iceland

(September 2011) by Gunnar Haraldsson and David Carey

890. Japan's New Growth Strategy to create demand and Jobs

(September 2011) by Randall S. Jones and Byungseo Yoo

889. Labour market reforms in Japan to improve growth and equity

(September 2011) by Randall S. Jones and Satoshi Urasawa

888. Education reform in Japan

(September 2011) by Randall S. Jones

887. The Political Economy of Climate Change Mitigation Policies: How to Build a Constituency to Address Global Warming?

(August 2011) by Alain de Serres, John Llewellyn and Preston Llewellyn

886. Climate-Change Policy in the United Kingdom

(August 2011) by Alex Bowen and James Rydge

885. Improving Access and Quality in the Indian Education System

(August 2011) by Sam Hill and Thomas Chalaux

884. How Institutions Shape the Distributive Impact of Macroeconomic Shocks: A DSGE Analysis (July 2011) by Rudiger Ahrend, Charlotte Moeser and Tommaso Monacelli

883. Can India Achieve Double-Digit Growth?

(July 2011) by Richard Herd, Paul Conway, Sam Hill, Vincent Koen and Thomas Chalaux

882. Predicting peaks and troughs in real house prices

(July 2011) by Linda Rousová and Paul van den Noord

881. Public sector spending efficiency in Estonia: healthcare and local government

(July 2011) by Zuzana Smidova 